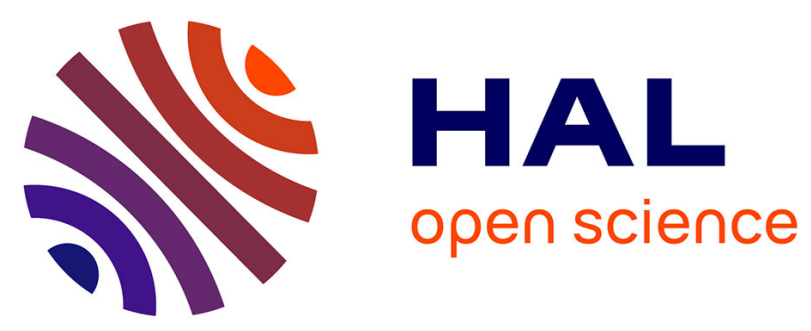

\title{
Role of the Metal Ion in Bio-Inspired Hydrogenase Models: Investigation of a Homodinuclear FeFe Complex vs Its Heterodinuclear NiFe Analogue \\ Lianke Wang, Marcello Gennari, Alexandre Barrozo, Jennifer Fize, Christian Philouze, Serhiy Demeshko, Franc Meyer, Maylis Orio, Vincent Artero, Carole Duboc
}

\section{To cite this version:}

Lianke Wang, Marcello Gennari, Alexandre Barrozo, Jennifer Fize, Christian Philouze, et al.. Role of the Metal Ion in Bio-Inspired Hydrogenase Models: Investigation of a Homodinuclear FeFe Complex vs Its Heterodinuclear NiFe Analogue. ACS Catalysis, 2020, 10 (1), pp.177-186. 10.1021/acscatal.9b03212 . hal-02406408

\section{HAL Id: hal-02406408 \\ https://hal.science/hal-02406408}

Submitted on 17 Nov 2020

HAL is a multi-disciplinary open access archive for the deposit and dissemination of scientific research documents, whether they are published or not. The documents may come from teaching and research institutions in France or abroad, or from public or private research centers.
L'archive ouverte pluridisciplinaire HAL, est destinée au dépôt et à la diffusion de documents scientifiques de niveau recherche, publiés ou non, émanant des établissements d'enseignement et de recherche français ou étrangers, des laboratoires publics ou privés. 


\title{
Role of the metal ion in bio-inspired hydrogenase models: investigation of a homodinuclear FeFe complex vs its heterodinuclear NiFe analogue
}

Lianke Wang, ${ }^{a}$ Marcello Gennari, ${ }^{a,}$ "* Alexandre Barrozo, ${ }^{b}$ Jennifer Fize, ${ }^{c}$ Christian Philouze, ${ }^{a}$ Serhiy Demeshko, ${ }^{\mathrm{d}}$ Franc Meyer, ${ }^{\mathrm{d}}$ Maylis Orio, ${ }^{\mathrm{b}}$ Vincent Artero, ${ }^{\mathrm{b}}$ Carole Duboc ${ }^{\mathrm{a}, *}$

${ }^{a}$ Univ. Grenoble Alpes, UMR CNRS 5250, Département de Chimie Moléculaire, 38000 Grenoble, France.

${ }^{b}$ Aix Marseille Univ, CNRS, Centrale Marseille, iSm2, Marseille (France)

${ }^{c}$ Univ. Grenoble Alpes, CNRS, CEA, IRIG, Laboratoire de Chimie et Biologie des Métaux, 38000 Grenoble, France

${ }^{d}$ Universität Göttingen, Institut für Anorganische Chemie, Tammannstrasse 4, D-37077 Göttingen, Germany

\begin{abstract}
In Nature, dihydrogen is catalytically produced by the [FeFe] and [NiFe] hydrogenases. Despite common structural features in their dinuclear active site, i.e. a thiolate-rich coordination sphere and $\mathrm{CO} / \mathrm{CN}^{-}$ligation, the synergetic way, in which the two metal sites act during catalysis, is specific for each enzyme. With the aim of understanding the role of the nature of the metal (Fe vs $\mathrm{Ni}$ ), we report on a homodinuclear FeFe complex, a parent of a previously reported NiFe complex, in order to compare their electrocatalytic activity for $\mathrm{H}_{2}$ production. The diiron complex [(CO) $\left.\mathrm{L}^{\mathrm{N} 2 \mathrm{~S} 2} \mathrm{Fe}^{\mathrm{II}} \mathrm{Fe}^{\mathrm{II}}(\mathrm{CO}) \mathrm{Cp}\right]^{+}$(with $\mathrm{L}^{\mathrm{N} 2 \mathrm{~S} 2}=$ 2,2'-(2,2'-bipyridine-6,6'-diyl)bis(1,1-diphenylethanethiolate and $\mathrm{Cp}=$ cyclopentadienyl), has been synthesized and fully characterized. In the solid state, it contains two $\mathrm{CO}$ ligands, one bound to the $\{\mathrm{FeCp}\}$ moiety in a semi-bridging manner and one terminally bound to the $\left\{\mathrm{FeL}^{\mathrm{N} 2 \mathrm{~S} 2}\right\}$ moiety. This dinuclear iron complex is thus not isostructural to $\left[\mathrm{L}^{\mathrm{N} 2 \mathrm{~S} 2} \mathrm{Ni}^{\mathrm{II}} \mathrm{Fe}^{\mathrm{II}}(\mathrm{CO}) \mathrm{Cp}\right]^{+}$, which contains a single $\mathrm{CO}$ ligand terminally bound to the Fe site. However, in low-concentrated MeCN solutions, the CO ligand coordinated to the $\left\{\mathrm{FeL}^{\mathrm{N} 2 \mathrm{~S} 2}\right\}$ moiety is removed, and the $\mathrm{CO}$ ligand bound to the $\{\mathrm{FeCp}\}$ moiety becomes fully bridging between the two Fe sites. Under such conditions, the diiron complex displays similar catalytic performances to the parent NiFe complex (a comparable overpotential, $\eta=730 \mathrm{mV}$ and $690 \mathrm{mV}$ and TON = 15 and 16, respectively). Cyclic voltammetry data give direct experimental evidence for an E[ECEC] mechanism, which was also previously proposed for the NiFe complex. However, the structure of the one-electron reduced species, the entry point of the catalytic cycle, slightly differs for the two systems: in [ $\left.\mathrm{L}^{\mathrm{N} 2 \mathrm{~S} 2} \mathrm{Ni}^{\mathrm{I}}(\mathrm{CO}) \mathrm{Fe}^{\mathrm{II}} \mathrm{Cp}\right]$, this is valence localized species on the site $\mathrm{Ni}$ and the $\mathrm{CO}$ ligand bridges the two metallic sites, while in [(CO) $\left.\mathrm{L}^{\mathrm{N} 2 \mathrm{~S} 2} \mathrm{FeFeCp}\right]$, this is a type II mixed-valence species (ref à ajouter) with the $\mathrm{CO}$ terminally-bound to the $\left\{\mathrm{FeL}^{\mathrm{N} 2 \mathrm{~S} 2}\right\}$ unit.
\end{abstract}




\section{Introduction}

Nature designed two distinct dinuclear catalysts to reversibly reduce protons into dihydrogen. Two metal ions act in synergy in such $\{$ MFeS2 $\}$ cores $(\mathrm{M}=\mathrm{Ni}$ or Fe, Scheme 1 ), present in the active site of the [NiFe] and [FeFe] hydrogenases ( $\mathrm{H}_{2}$ ases), respectively. ${ }^{1-6}$ Although both enzymes involve a similar ECEC mechanism ${ }^{7}$ to produce $\mathrm{H}_{2}$ ( $\mathrm{E}=$ electron transfer, $\mathrm{C}=$ chemical reaction, here corresponding to a proton transfer), different types of intermediates and strategies are involved. ${ }^{1,8}$ For the [NiFe] $\mathrm{H}_{2}$ ase, only the $\mathrm{Ni}$ ion participates in the redox chemistry by cycling between oxidation states ranging from +I to +III. The Fe site remains in the +II oxidation states but contributes in the stabilization of hydride ligands, bridging both metal centers in two key intermediates in the catalytic cycle. ${ }^{9-12}$ Regarding [FeFe] $\mathrm{H}_{2}$ ase, the redox chemistry also occurs at a single metal site (the distal iron center, $\mathrm{Fe}_{\mathrm{d}}$ ). It only cycles between two oxidation states ( $+\mathrm{I}$ and $+\mathrm{II}$ ), and is involved in the stabilization of a terminal hydride ligand. The second iron center (proximal $\mathrm{Fe}$ site, $\mathrm{Fe}_{\mathrm{p}}$ ) acts as a scaffold through the positioning of the doubly-bridging azadithiolate ligand that plays a key role as proton relay. Besides it also connects $\mathrm{Fe}_{\mathrm{d}}$ with a [4Fe4S] cluster that acts as an electron reservoir and cycles between +1 and +2 charge states during the catalytic cycle. ${ }^{13-15}$

In this context, chemists applied two main approaches to mimic the active sites of these two enzymes. ${ }^{2,}$ 16-17 Bio-inspired NiFe catalysts for $\mathrm{H}_{2}$ production have been mainly designed with a $\{\mathrm{NiFeS} 2\}$ core consisting of a Ni site in a thiolate-rich environment and a Fe site with $\mathrm{CO}, \mathrm{CN}^{-}, \mathrm{Cp}^{-}$or carbene ligands. The main objective was to localize the redox chemistry at the Ni site. ${ }^{18}$ In the case of the FeFe mimics, even if the majority also displays a $\{\mathrm{Fe} 2 \mathrm{~S} 2\}$ core, a special interest has been focused on the bridging azadithiolate ligand that bears an amine proton relay. When possible, the incorporation of an electron transfer mediator in the second coordination sphere, such as a [4Fe4S] cluster ${ }^{19}$ or a ferrocenyl group, ${ }^{20}$ has also been considered. ${ }^{21}$ Due to these specific requirements, a direct comparison between the hydrogen evolution reaction (HER) activity of NiFe and FeFe $\mathrm{H}_{2}$ ase mimics with the same coordination environment has not been reported so far. Two series of $\mathrm{NiFe}$ and FeFe complexes with similar environments have been described but the complexes are not isostructural: [(dppe)Ni $(\mu-$ pdt)Fe(CO) $\left.)_{3}\right] /\left[(\mathrm{dppe})(\mathrm{CO}) \mathrm{Fe}(\mu-\mathrm{pdt}) \mathrm{Fe}(\mathrm{CO})_{3}\right]^{17}, \quad{ }^{22-23}$ and $\left[\left(\mathrm{L}^{\prime}{ }^{\mathrm{N} 2 \mathrm{~S}} 2\right) \mathrm{NiFe}(\mathrm{CO}) \mathrm{Cp}\right]^{+} /$ $\left[\left(\mathrm{L}^{\prime}{ }^{\mathrm{N} 2 \mathrm{~S} 2}\right)(\mathrm{Fe}-\mathrm{NO}) \mathrm{Fe}(\mathrm{CO}) \mathrm{Cp}\right]^{+}\left(\mathrm{L}^{\prime \mathrm{N} 2 \mathrm{~S} 2}=\text { bismercaptoethyl diazacycloheptane }\right)^{24}$ (Scheme 1). Regarding the first series, even if both complexes can generate similar hydride intermediates, only the $\mathrm{NiFe}$ derivate catalyses $\mathrm{H}_{2}$ production. As for the second series, a $\{\mathrm{Fe}(\mathrm{NO})\}^{7}$ is required to stabilize the FeFe complex in such an environment. Because of the peculiar redox character of the $\{\mathrm{Fe}(\mathrm{NO})\}^{\mathrm{n}}$ unit, it is difficult to conclude on the effect of the nature of the metal, Ni vs Fe, on the catalytic process in this specific case.

We have recently investigated the propensity of a NiFe complex, $\left[\mathrm{L}^{\mathrm{N} 2 \mathrm{~S} 2} \mathrm{Ni}^{\mathrm{II}} \mathrm{Fe} \mathrm{II}^{\mathrm{II}} \mathrm{Cp}(\mathrm{CO})\right]^{+}$ ( $\left\{\mathbf{N i F e}^{\prime}\right\}_{\text {Co }}^{+}$, with $\mathrm{L}^{\mathrm{N} 2 \mathrm{~S} 2}=2,2^{\prime}$-(2,2'-bipyridine-6,6'-diyl)bis(1,1'-diphenylethanethiolate), $\mathrm{Fe}^{\prime}=$ in the $\{\mathrm{FeCp}\}$ moiety), to mimic the structural and functional properties of [NiFe] $\mathrm{H}_{2}$ ase (Scheme 1). This efficient electrocatalyst for $\mathrm{H}_{2}$ production displays redox 
chemistry mainly centered on the Ni-N2S2 site, and two catalytic intermediates, including a hydride species, have been identified in homogeneous conditions. ${ }^{25-28}$ In this work, we report the structure, properties and HER reactivity in homogeneous conditions of the parent FeFe complex, $\left\{\mathbf{F e F e}^{\prime}\right\}_{\mathbf{C o} / \mathbf{2} \mathbf{c o}}^{+}$(Scheme 1), with the aim of comparing it with its NiFe counterpart and of understanding the role of the metal in the N2S2 site, Ni vs Fe.

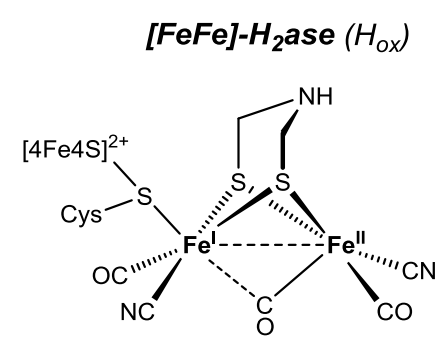

[FeFe]-H ase mimics

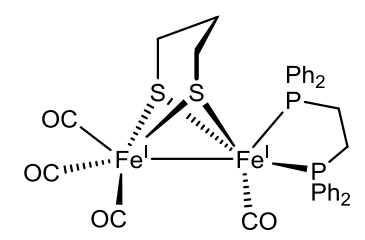

$\left[(\mathrm{dppe})(\mathrm{CO}) \mathrm{Fe}(\mu-\mathrm{pdt}) \mathrm{Fe}(\mathrm{CO})_{3}\right]$

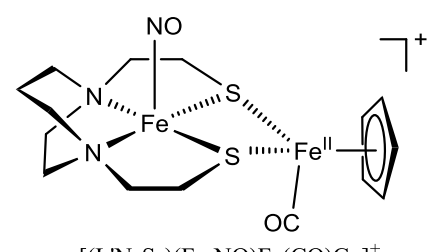

$\left[\left(\mathrm{L}^{\prime} \mathrm{N}_{2} \mathrm{~S}_{2}\right)(\mathrm{Fe}-\mathrm{NO}) \mathrm{Fe}(\mathrm{CO}) \mathrm{Cp}\right]^{+}$

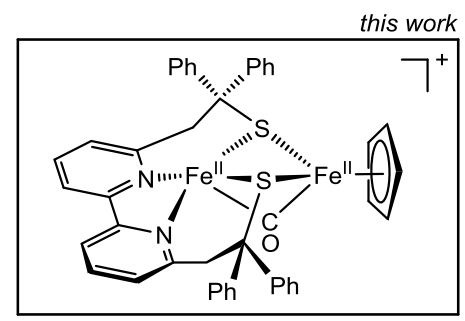

$\left\{\mathrm{FeFe}_{\mathrm{co}}^{+}\right.$
[NiFe]-H ase $\left(\mathrm{Ni}-\mathrm{SI} \mathrm{I}_{\mathrm{a}}\right)$

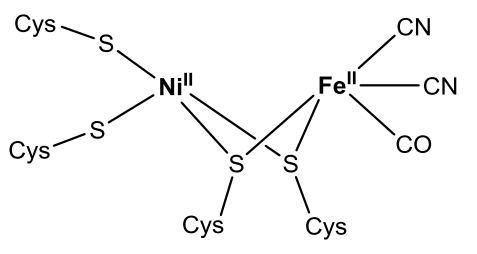

[NiFe]- $\mathrm{H}_{2}$ ase mimics

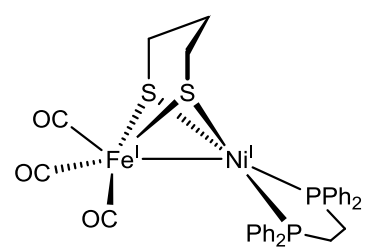

$\left[(\mathrm{dppe}) \mathrm{Ni}(\mu-\mathrm{pdt}) \mathrm{Fe}(\mathrm{CO})_{3}\right]$

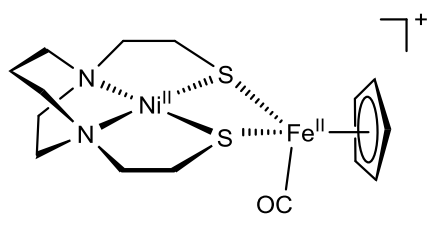

$\left[\left(\mathrm{L}^{\prime} \mathrm{N}_{2} \mathrm{~S}_{2}\right) \mathrm{NiFe}(\mathrm{CO}) \mathrm{Cp}\right]^{+}$

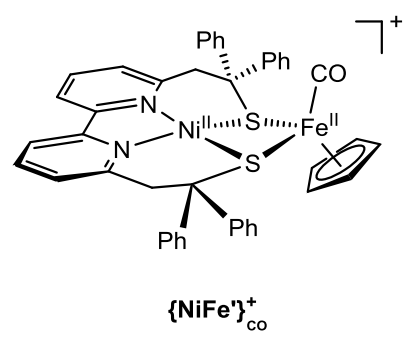

Scheme 1. Active sites of the [FeFe] and [NiFe] $\mathrm{H}_{2}$ ases (resting state), selected examples of mimics discussed in the text.

\section{Results and Discussion}

Synthesis and solid-state characterization of $\left\{\mathbf{F e F e}^{\prime}\right\}_{2 \mathbf{C O}}^{+}$. The tetrafluoroborate salt of the diiron complex [(CO)L $\left.\mathrm{L}^{\mathrm{N} 2 \mathrm{~S} 2} \mathrm{Fe}^{\mathrm{II}} \mathrm{Fe}^{\mathrm{II}}(\mathrm{CO}) \mathrm{Cp}\right]^{+}$(with $\mathrm{L}^{\mathrm{N} 2 \mathrm{~S} 2}=2,2^{\prime}-\left(2,2^{\prime}\right.$-bipyridine-6,6'diyl)bis(1,1-diphenylethanethiolate and $\mathrm{Cp}=$ cyclopentadienyl), $\left\{\mathbf{F e F e}^{\prime}\right\}_{2 \mathbf{C o}}^{+}$, was isolated as a brown solid by reacting the $\left[\mathrm{CpFe}(\mathrm{CO})(\mathrm{MeCN})_{2}\right] \mathrm{BF}_{4}$ precursor with the 
previously reported dinuclear $\mathrm{Fe}^{\mathrm{II}}$ complex $\left[\mathrm{Fe}^{\mathrm{II}}{ }_{2}\left(\mathrm{~L}^{\mathrm{N} 2 \mathrm{~S} 2}\right)\left(\mathrm{HL}^{\mathrm{N} 2 \mathrm{~S} 2}\right)\right] \mathrm{BF}_{4}\left(\left[\mathrm{Fe}_{2} \mathrm{SH}_{\mathrm{B}} \mathrm{BF}_{4}\right)^{29}\right.$ in MeCN at room temperature (Scheme 2). The formation of $\left\{\mathbf{F e F e}^{\prime}\right\}_{2 \mathbf{C o}}^{+}$is the result of the cleavage of the $\left[\mathrm{Fe}_{2}{ }^{\mathbf{S H}}\right]^{+}$complex making two thiolate-donor ligands available for binding the $[\mathrm{CpFe}(\mathrm{CO})]^{+}$moiety. Two iron-bound $\mathrm{CO}$ molecules are present in the structure of $\left\{\mathbf{F e F e}^{\prime}\right\}_{2 \mathrm{Co}}^{+}$(see below), so that the use of an excess of $[\mathrm{CpFe}(\mathrm{CO})]^{+}\left(4\right.$ equiv. vs $\left[\mathbf{F e}_{2} \mathbf{S H}^{+}\right.$) as $\mathrm{CO}$ source is required for its synthesis. The diffusion of $\mathrm{Et}_{2} \mathrm{O}$ into an $\mathrm{MeCN}$ solution of $\left\{\mathbf{F e F e}^{\prime}\right\}_{2 \mathrm{Co}}^{+}$in the presence of tetrabutylammonium perchlorate provides black needle crystals suitable for single-crystal X-ray crystallographic analysis.

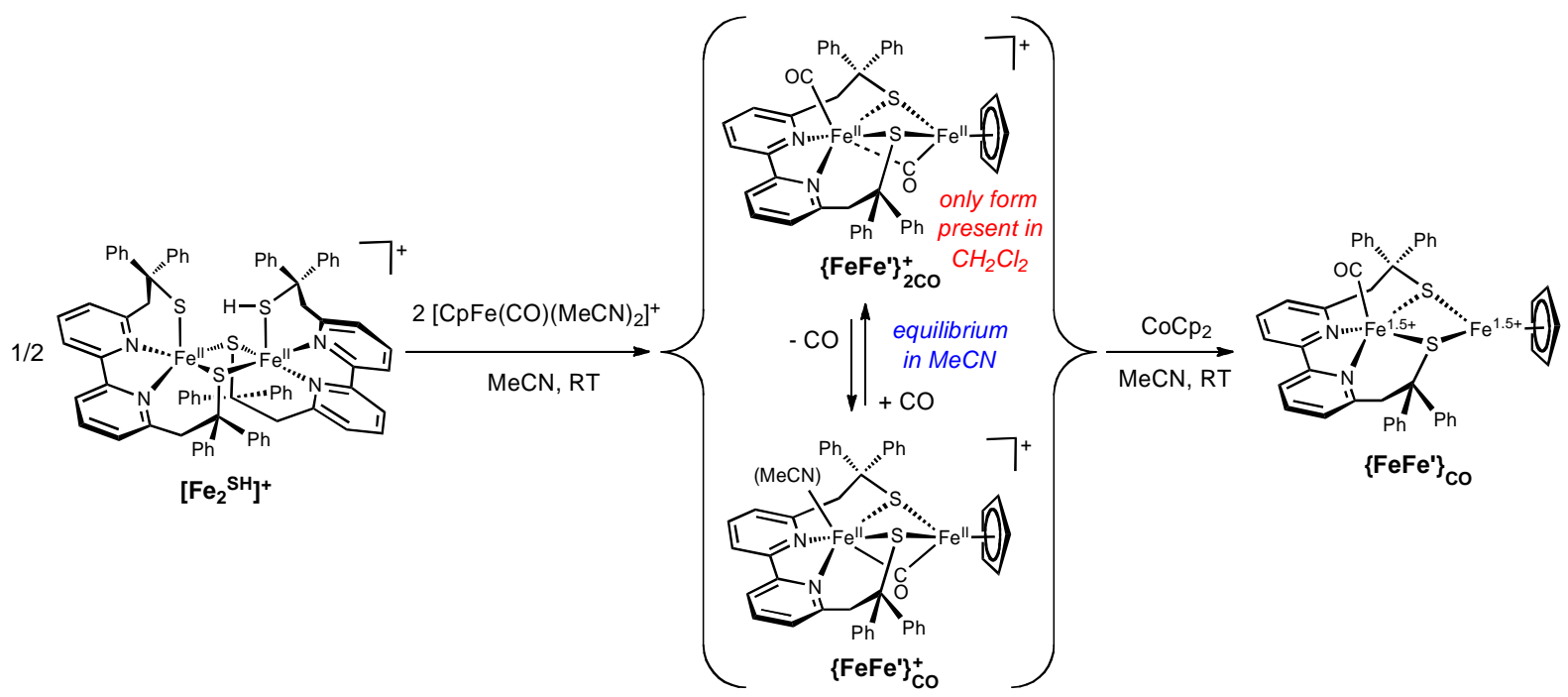

Scheme 2. Synthesis of the diiron complexes discussed in this work. The notations Fe and $\mathbf{F e}^{\prime}$ refer to the $\left\{\mathrm{FeL}^{\mathrm{N} 2 \mathrm{~S}}\right\}$ and $\{\mathrm{FeCp}\}$ moieties, respectively.

The X-ray structure of the perchlorate salt of $\left\{\mathbf{F e F e}^{\prime}\right\}_{2 \mathbf{c o}}^{+}$(Figure 1, left, and Tables S1S2) reveals a $\{\mathrm{Fe} 2 \mathrm{~S} 2\}$ core in which two inequivalent iron(II) centers are thiolatebridged. The Fe1 ion (corresponding to the $\mathbf{F e}$ unit in $\left\{\mathbf{F e F e}^{\prime}\right\}_{2 \mathrm{CO}}^{+}$) is coordinated by one terminally bound CO molecule, two sulfur and two nitrogen atoms of $\mathrm{L}^{\mathrm{N} 2 \mathrm{~S} 2}$, resulting in a distorted square pyramidal geometry with a $\tau_{5}$ value of 0.12 . The Fe2 ion (corresponding to the $\mathbf{F e}^{\prime}$ unit in $\left\{\mathbf{F e F e}^{\prime}\right\}_{2 \mathbf{C O}}^{+}$) is surrounded by a CO molecule, two bridging sulfur atoms of $\mathrm{L}^{\mathrm{N} 2 \mathrm{~S} 2}$ and a $\eta^{5}$-coordinated $\mathrm{Cp}$ ligand. No Fe $\cdots \mathrm{Fe}$ interaction is present, in agreement with the observed Fe $\cdots$ Fe distance of 2.5611(12) A. The latter is similar to the $\mathrm{Fe} \cdots \mathrm{Fe}$ distances found in [FeFe] hydrogenases in the resting $H_{o x}$ state (2.55-2.62 Å).5, 15 The Fe1S1S2 plane is almost perpendicular to the Fe2S1S2 plane with a dihedral angle of 87.93(6) ${ }^{\circ}$. The CO ligand coordinated to $\mathrm{Fe} 2$ is semi-bridging between the two iron centers (Fe1...C44 and Fe2-C44 distances of 2.345(6) $\AA$ and $1.770(6) \AA$, respectively), like in the enzyme. Indeed, the crystallographic structure of the $[\mathrm{FeFe}]$ hydrogenase from $D$. desulfuricans (presence of two non-equivalent molecules) displays Fe-CO distances of $2.40 \AA$ (2.59 $\AA$ ) and $1.69 \AA$ (1.69 $\AA$ ) in the $H_{\text {red }}$ state. ${ }^{30}$ 

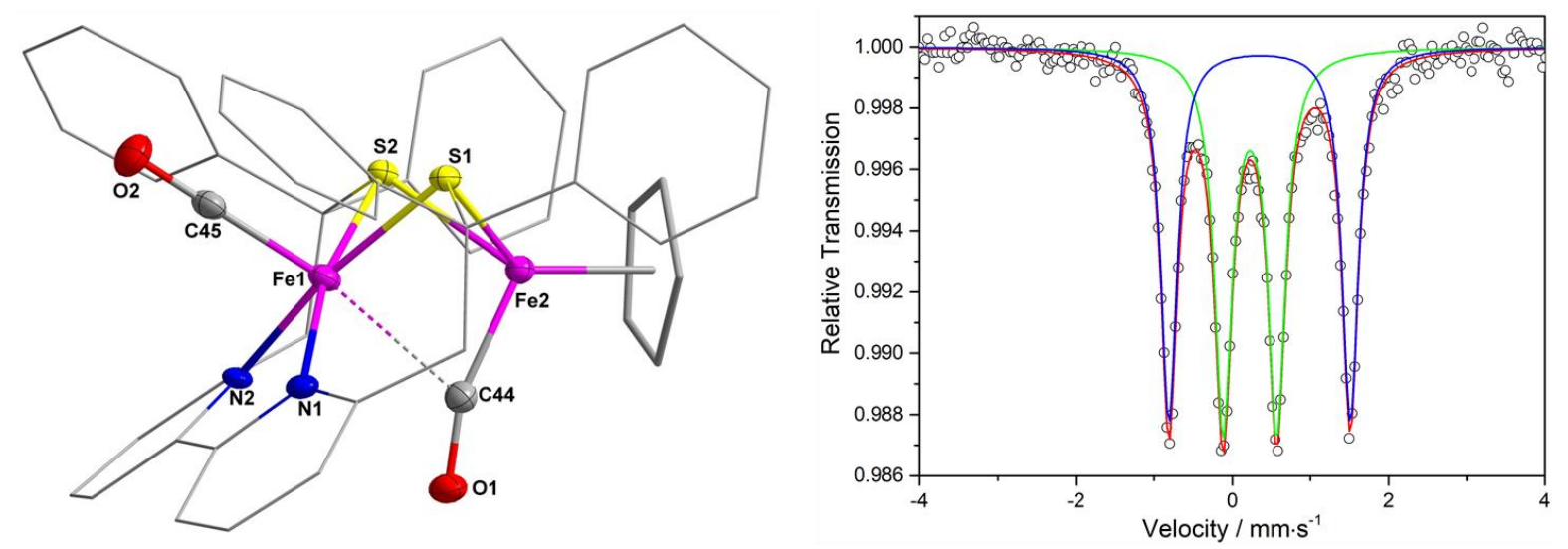

Figure 1. (left) X-ray crystal structure of $\left\{\mathbf{F e F e}^{\prime}\right\}_{2 \mathbf{C o}^{+}}^{+} \mathrm{ClO}_{4} \cdot \mathrm{MeCN}$ with partial thermal ellipsoids drawn at $30 \%$ probability. For clarity, the co-crystallized solvent and the perchlorate counterion have been omitted and the aromatic groups are drawn as lines. (right) Zero-field ${ }^{57} \mathrm{Fe}$ Mössbauer spectrum (experimental + simulation) of solid $\left\{\mathbf{F e F e}^{\prime}\right\}_{2 \mathrm{Co}}^{+}$recorded at $80 \mathrm{~K}$.
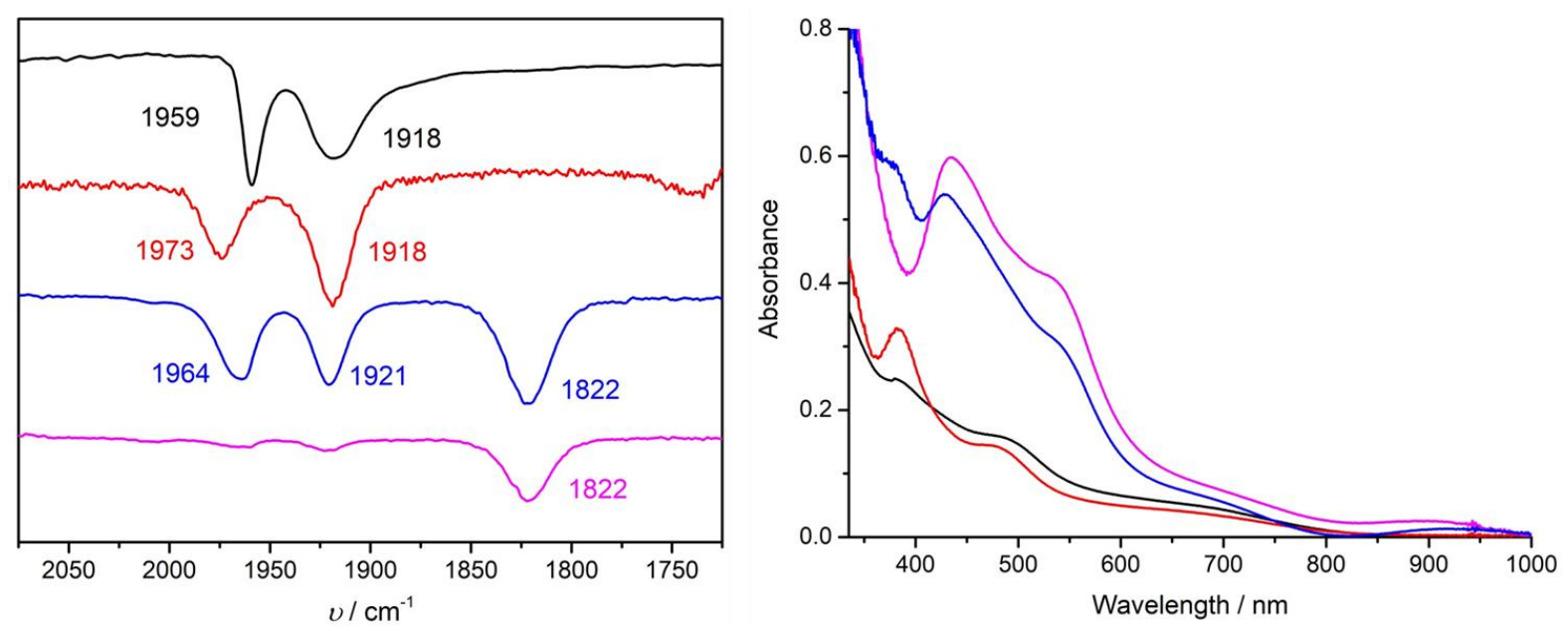

Figure 2. (left) IR spectra of $\left\{\mathbf{F e F e}^{\prime}\right\}_{2}^{+} \mathrm{Co}$ in the solid state (black), in $\mathrm{CH}_{2} \mathrm{Cl}_{2}(0.4 \mathrm{mM}$, red), and in MeCN (1.0 mM, blue; $0.2 \mathrm{mM}$, pink) solutions; (right) UV-vis spectra of $\left\{\mathbf{F e F e}^{\prime}\right\}_{2 \mathrm{Co}}^{+}$ in the solid state (black), in $\mathrm{CH}_{2} \mathrm{Cl}_{2}(0.4 \mathrm{mM}, 2 \mathrm{~mm}$ path length, red), and in MeCN (1.0 $\mathrm{mM}, 2 \mathrm{~mm}$ path length, blue; $0.2 \mathrm{mM}, 10 \mathrm{~mm}$ path length, pink) solutions.

The powder IR spectrum of $\left\{\mathbf{F e F e}^{\prime}\right\}_{2}^{+}$co (Figure 2, left) displays two CO stretching vibration bands at 1959 and $1918 \mathrm{~cm}^{-1}$, assigned to the terminal and semi-bridging CO ligands, respectively (Table 1). The powder zero-field ${ }^{57} \mathrm{Fe}$ Mössbauer spectrum of $\left\{\mathbf{F e F e}^{\prime}\right\}_{2 \text { co }}^{+}$recorded at $80 \mathrm{~K}$ (Figure 1, right) exhibits two quadrupole doublets with $\delta=$ $0.23 \mathrm{~mm} \cdot \mathrm{s}^{-1} ; \Delta \mathrm{E}_{\mathrm{Q}}=0.69 \mathrm{~mm} \cdot \mathrm{s}^{-1}$ for $\mathrm{Fe}_{\mathrm{A}}$ and $\delta=0.35 \mathrm{~mm} \cdot \mathrm{s}^{-1} ; \Delta \mathrm{E}_{\mathrm{Q}}=2.32 \mathrm{~mm} \cdot \mathrm{s}^{-1}$ for $\mathrm{Fe}_{\mathrm{B}}$, consistent with two distinct low spin iron(II) centers (Table 1). Based on the Mossbauer parameters of the $\mathrm{Fe}^{\mathrm{II}}$ center from the previously reported parent $\left\{\mathbf{N i F e}^{\prime}\right\}_{\mathbf{C o}}^{+}$complex $(\delta$ $=0.39 \mathrm{~mm} \cdot \mathrm{s}^{-1}$ and $\left.\Delta \mathrm{E}_{\mathrm{Q}}=1.82 \mathrm{~mm} \cdot \mathrm{s}^{-1}\right),{ }^{25} \mathrm{Fe}_{\mathrm{B}}$ can be assigned to the $\mathrm{Fe}^{\mathrm{II}}$ ion located in the Fe' subunit. Consequently, $\mathrm{Fe}_{\mathrm{A}}$ corresponds to the $\mathrm{Fe}^{\mathrm{II}}$ ion in the $\mathbf{F e}$ subunit. The solid state UV-vis spectrum of $\left\{\mathbf{F e F e}^{\prime}\right\}_{2}^{+}$co (Figure 2) displays two absorption bands at around 
$381 \mathrm{~nm}$ and $483 \mathrm{~nm}$ with a broad shoulder around $650 \mathrm{~nm}$. The EPR spectrum of $\left\{\mathbf{F e F e}^{\prime}\right\}_{2 \mathrm{Co}}^{+}$is silent, in agreement with the low spin character of both Fe $\mathrm{FI}^{\mathrm{II}}$ ions.

Table 1. Experimental and (TD)-DFT predicted spectroscopic parameters of the different characterized complexes and DFT-optimized structures $\left({ }^{*}\right)$.

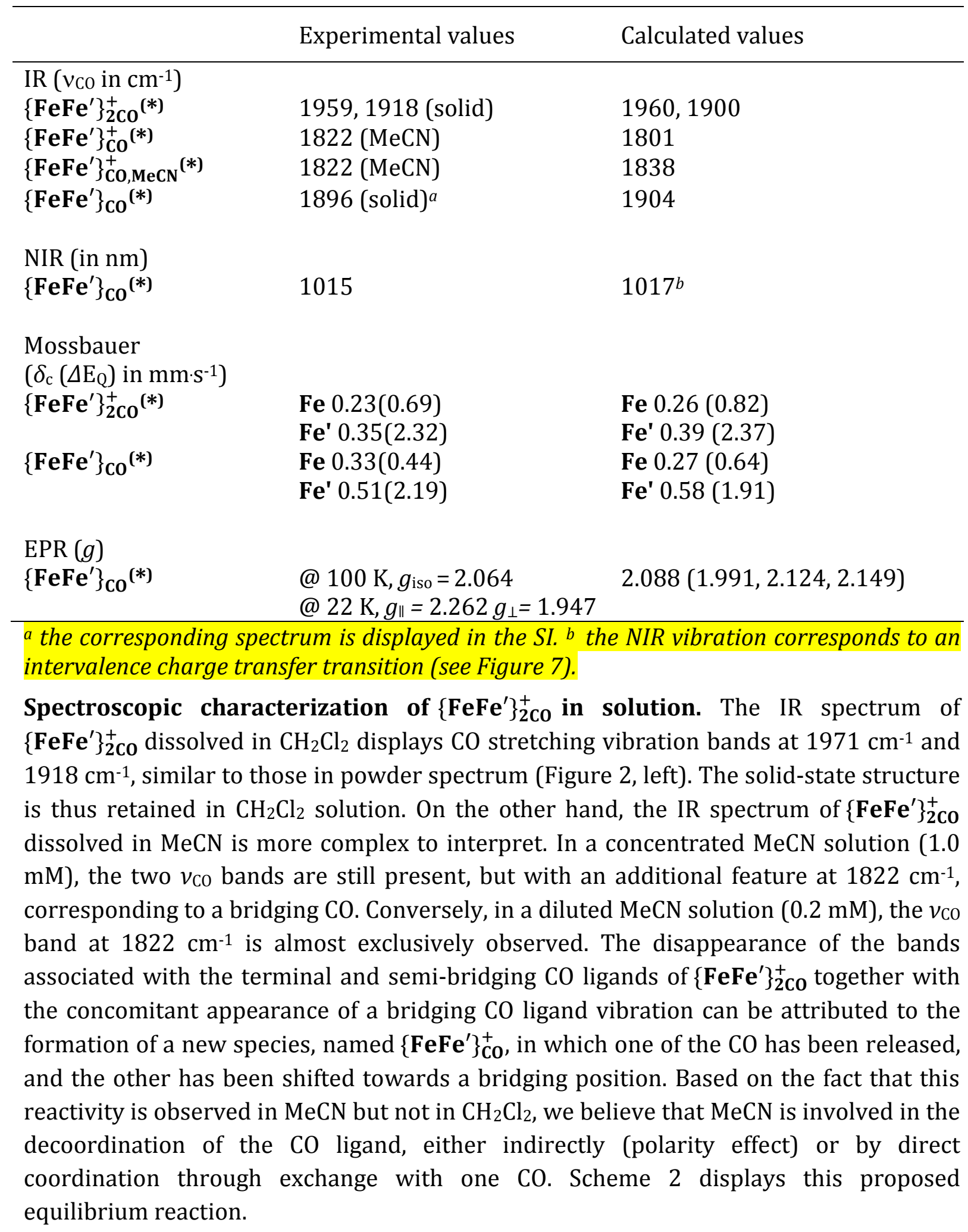




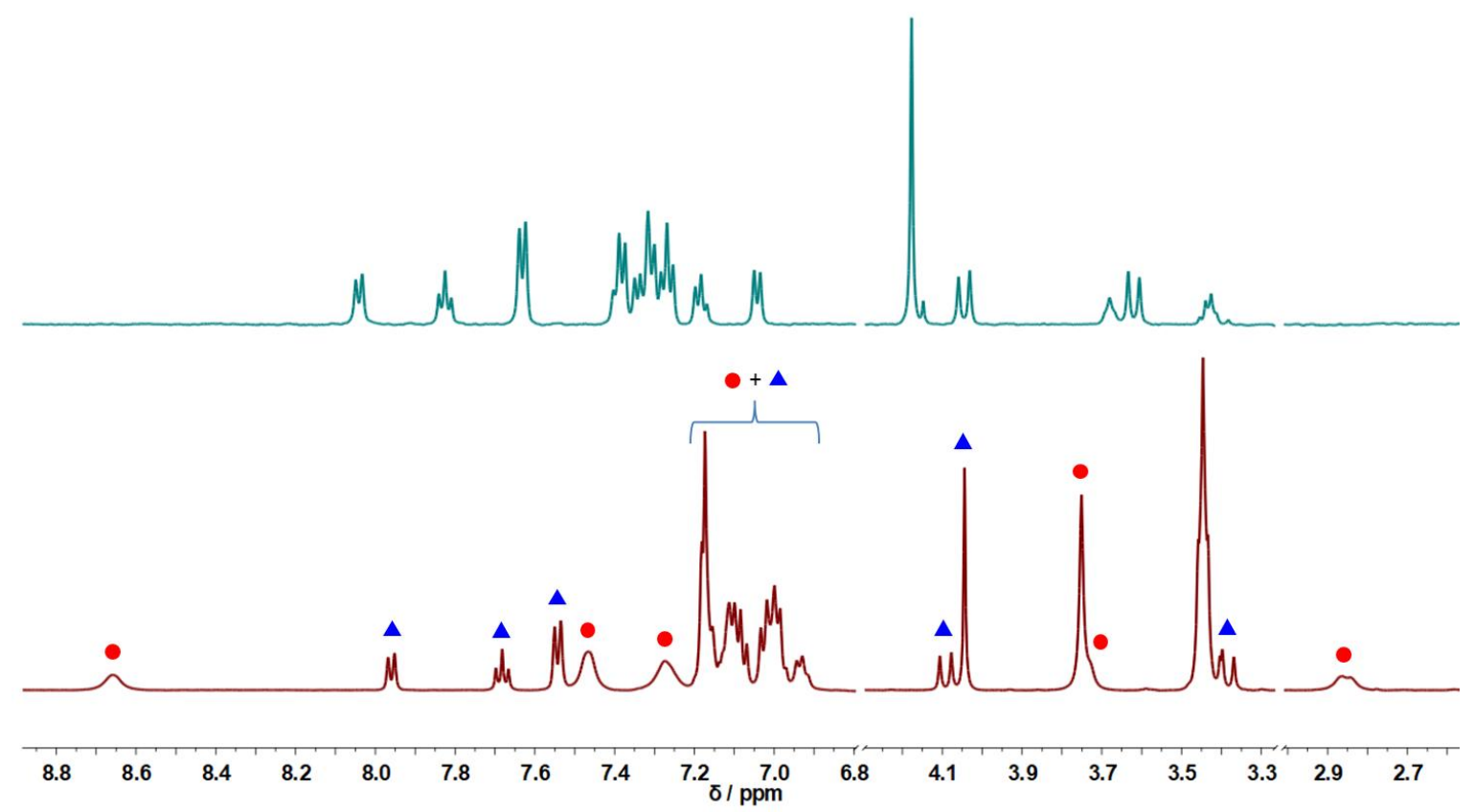

Figure 3. ${ }^{1} \mathrm{H}$ NMR $(500 \mathrm{MHz})$ spectra of $\left\{\mathbf{F e F e}^{\prime}\right\}_{2 \mathbf{C o}}^{+}$dissolved in $\mathrm{CD}_{2} \mathrm{Cl}_{2}(0.4 \mathrm{mM}$, above, all the shown peaks are assigned to $\left.\left\{\mathbf{F e F e}^{\prime}\right\}_{2}^{+} \mathbf{C o}\right)$ or $\mathrm{CD}_{3} \mathrm{CN}(1.0 \mathrm{mM}$, below, peak attribution: blue triangles $=\left\{\mathbf{F e F e}^{\prime}\right\}_{\text {2Co }}^{+}$; red circles $\left.=\left\{\mathbf{F e F e}^{\prime}\right\}_{\text {Co }}^{+}\right)$.

Accordingly, in the ${ }^{1} \mathrm{H}$ NMR spectrum of $\left\{\mathbf{F e F e}^{\prime}\right\}_{2}^{+} \mathbf{C o}$ in $\mathrm{CD}_{2} \mathrm{Cl}_{2}$ only one set of signals is observed, in accordance with the molecular structure observed in solid state, while two set of signals are present in $\mathrm{CD}_{3} \mathrm{CN}$ (1.0 mM solution), corresponding to $\left\{\mathbf{F e F e}^{\prime}\right\}_{2}^{+} \mathbf{C o}$ and $\left\{\mathbf{F e F e}^{\prime}\right\}_{\text {co }}^{+}$(Figure 3).

The UV-vis signature of $\left\{\mathbf{F e F e}^{\prime}\right\}_{2}^{+} \mathbf{C o}$ in $\mathrm{CH}_{2} \mathrm{Cl}_{2}$ and $\mathrm{MeCN}$ solutions (Figure 2, right) confirms the speciation determined by IR and ${ }^{1} \mathrm{H}$ NMR. The spectrum in $\mathrm{CH}_{2} \mathrm{Cl}_{2}$ (main bands: $382 \mathrm{~nm}, 4110 \mathrm{M}^{-1} \cdot \mathrm{cm}^{-1}$ and $475 \mathrm{~nm}, 1800 \mathrm{M}^{-1} \cdot \mathrm{cm}^{-1}$ ) is similar to the solid-state spectrum, confirming that the structure of $\left\{\mathbf{F e F e}^{\prime}\right\}_{2}^{+} \mathbf{C o}$ is retained in $\mathrm{CH}_{2} \mathrm{Cl}_{2}$ solution. In $\mathrm{MeCN}$, at high concentration $(1.0 \mathrm{mM})$, the three absorption bands at $381 \mathrm{~nm}, 429 \mathrm{~nm}$ and $536 \mathrm{~nm}$ correspond to a mixture of both $\left\{\mathbf{F e F e}^{\prime}\right\}_{2 \mathbf{C O}}^{+}$and $\left\{\mathbf{F e F e}^{\prime}\right\}_{\mathbf{C O}}^{+}$, whereas at low concentration $(0.2 \mathrm{mM})$, the spectrum shows only the absorption features of $\left\{\mathbf{F e F e}^{\prime}\right\}_{\mathbf{C O}}^{+}$, i.e. two bands at $434 \mathrm{~nm}\left(2989 \mathrm{M}^{-1} \cdot \mathrm{cm}^{-1}\right)$ and $536 \mathrm{~nm}\left(2024 \mathrm{M}^{-1} \cdot \mathrm{cm}^{-1}\right)$.

The equilibrium shown in Scheme 2 can be directed towards the formation of either $\left\{\mathbf{F e F e}^{\prime}\right\}_{2 \mathbf{C o}}^{+}$or $\left\{\mathbf{F e F e}^{\prime}\right\}_{\text {Co }}^{+}$by tuning the experimental conditions. When $\mathrm{CO}$ is bubbled into the mixture of both species in $\mathrm{MeCN}\left(0.5 \mathrm{mM}\left\{\mathbf{F e F e}^{\prime}\right\}_{2 \mathbf{2 0}}^{+}\right)$, the band at $381 \mathrm{~nm}$ increases, while those at 429 and $536 \mathrm{~nm}$ disappear with the concomitant appearance of an additional absorption band at $472 \mathrm{~nm}$ (Figure 4, left). The resulting UV-vis spectrum is similar to that of $\left\{\mathbf{F e F e}^{\prime}\right\}_{2}^{+} \mathbf{C o}$ in $\mathrm{CH}_{2} \mathrm{Cl}_{2}$, indicating that $\mathrm{CO}$ bubbling leads to the quantitative formation of the $\left\{\mathbf{F e F e}^{\prime}\right\}_{2 \mathbf{C o}}^{+}$complex also in MeCN. When CO is removed by argon bubbling from the CO-saturated MeCN solution of $\left\{\mathbf{F e F e}^{\prime}\right\}_{2 \mathrm{Co}}^{+}$(Figure 4, right), the two bands at 381 and $472 \mathrm{~nm}$ disappear and the two bands characteristic of $\left\{\mathbf{F e F e}^{\prime}\right\}_{\text {co }}^{+}$ newly appear. In both forward and backward processes, an isosbestic point at $415 \mathrm{~nm}$ is observed, demonstrating that only the two $\left\{\mathbf{F e F e}^{\prime}\right\}_{2 \text { co }}^{+}$and $\left\{\mathbf{F e F e}^{\prime}\right\}_{\text {co }}^{+}$species are involved in the equilibrium shown in Scheme 2. 

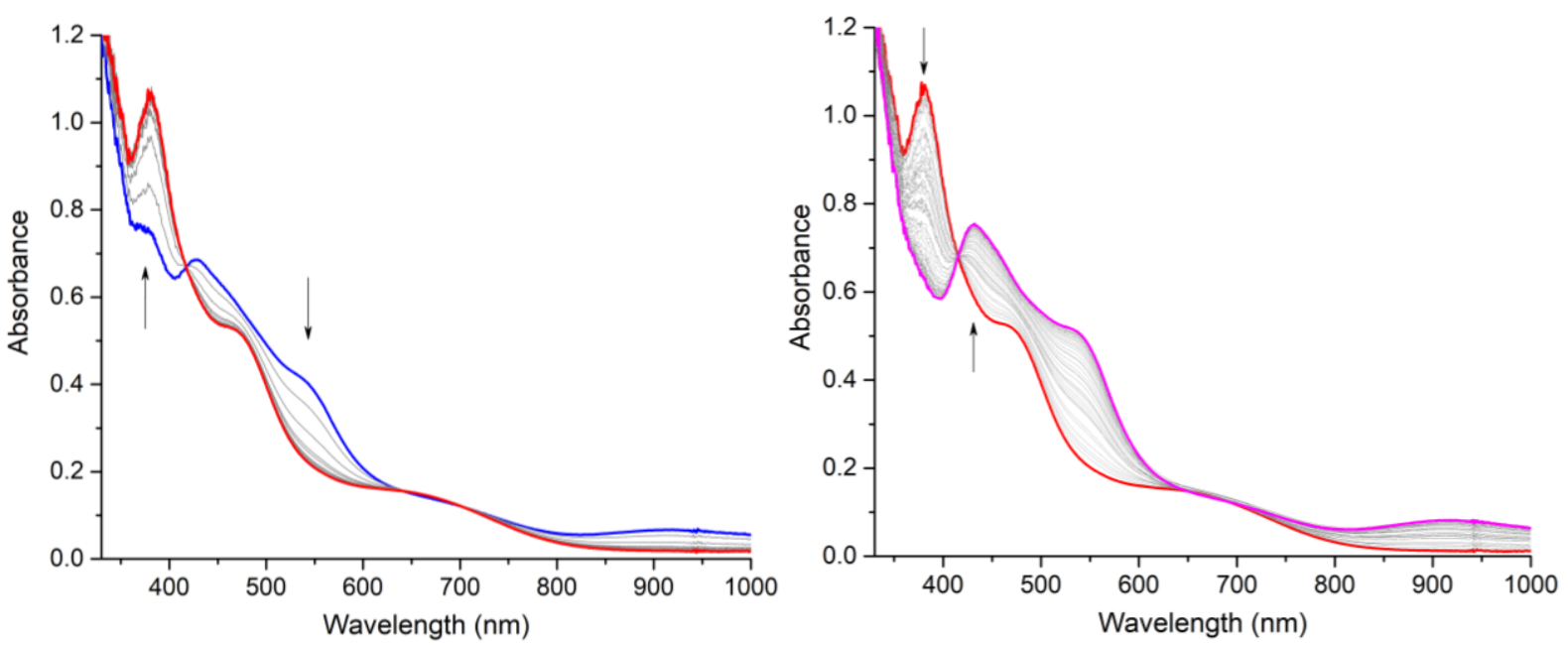

Figure 4. (left) UV-vis spectra of $\left\{\mathbf{F e F e}^{\prime}\right\}_{2 \mathrm{Co}}^{+}$dissolved in $\mathrm{MeCN}(0.5 \mathrm{mM}, 5 \mathrm{~mm}$ path length) before (blue line), during (grey lines) and after (red line) bubbling CO. The COsaturated solution of $\left\{\mathbf{F e F e}^{\prime}\right\}_{2}^{+} \mathbf{c o}$ is successively bubbled with argon and the corresponding UV-vis monitoring is shown on the right (before Ar-bubbling: red line, during: grey lines, after: magenta line).

To further investigate the structural and spectroscopic properties of $\left\{\mathbf{F e F e}^{\prime}\right\}_{\text {co }}^{+}$, DFT calculations have been performed. We initially validated our approach through the study of $\left\{\mathbf{F e F e}^{\prime}\right\}_{2 \mathrm{CO}}^{+}$. Its optimized structure, $\left\{\mathbf{F e F e}^{\prime}\right\}_{2 \mathrm{Co}}^{+}$, displays structural parameters (Table 1) and predicted $v_{\mathrm{CO}}$ vibrations that are fully consistent with the experimental data (less than $8 \mathrm{pm}$ of difference between predicted and experimental metal-ligand bond lengths; $v_{\mathrm{CO}}{ }^{\text {calc }}$ at 1900 and $1960 \mathrm{~cm}^{-1} v s v_{\mathrm{CO}} \exp ^{\exp } 1918$ and $1959 \mathrm{~cm}^{-1}$ ). The Mössbauer parameters have been also predicted by DFT and the calculated parameters are well consistent the experimental data confirming our previous attribution: for the $\mathbf{F e}$ unit, $\delta_{\text {calc }}=0.26 \mathrm{~mm} \cdot \mathrm{s}^{-1} ; \Delta \mathrm{E}_{\mathrm{Qcalc}}=0.82 \mathrm{~mm} \cdot \mathrm{s}^{-1}$ and for the $\mathbf{F e}^{\prime}$ unit, $\delta_{\text {calc }}=0.39 \mathrm{~mm} \cdot \mathrm{s}^{-1} ; \Delta \mathrm{E}_{\mathrm{Qcalc}}$ $=2.37 \mathrm{~mm} \cdot \mathrm{s}^{-1}($ Table 1$)$.

For $\left\{\mathbf{F e F e}^{\prime}\right\}_{\text {co }}^{+}$, several structures containing only one metal-bound $\mathrm{CO}$ have been optimized with or without an iron-bound MeCN molecule. Two calculated structures are consistent with the experimental $v_{\mathrm{CO}}$ vibration at $1822 \mathrm{~cm}^{-1}$ : (i) one with a bridging CO, $v_{\mathrm{CO}}{ }^{\text {calc }}=1801 \mathrm{~cm}^{-1}$ and no coordinated $\mathrm{MeCN}\left(\left\{\mathbf{F e F e}^{\prime}\right\}_{\text {Co }}^{+}{ }^{*}\right)$ and (ii) one with a bridging $\mathrm{CO}$ and a MeCN molecule coordinated to the Fe center, $v_{\mathrm{CO}}$ calc $=1838 \mathrm{~cm}^{-1}$ $\left(\left\{\mathbf{F e F e}^{\prime}\right\}_{\mathbf{C} 0, \mathbf{M e C N}}^{+}{ }^{*}\right)$. Considering the acetonitrile binding energy, the calculated free energy difference (1.9 kcal.mol-1) between these two species is consistent with the presence of both complexes in equilibrium (for the sake of simplicity it will be referred to $\left\{\mathbf{F e F e}^{\prime}\right\}_{\text {Co }}^{+}$in the rest of the manuscript).

Electrochemical properties of $\left\{\mathbf{F e F e}^{\prime}\right\}_{\mathbf{c o}}^{+}$. The electrochemical properties of the diiron(II) complex have been examined by cyclic voltammetry (CV) in MeCN at $0.2 \mathrm{mM}$ concentration: under these conditions only $\{\mathbf{F e F e}\}_{\text {Co }}^{+}$, and not $\{\mathbf{F e F e}\}_{2}^{+} \mathbf{C o}$, is present as 
shown by IR. The CV (Figure 5) exhibits two diffusion-controlled reversible one-electron reduction waves at $E_{1 / 2}=-1.21 \mathrm{~V}(\Delta E=91 \mathrm{mV})$ and $E_{1 / 2}=-1.65 \mathrm{~V}(\Delta E=90 \mathrm{mV})$ versus $\mathrm{Fc}^{+} / 0$. The first cathodic process is assigned to the reduction of $\left\{\mathbf{F e F e}^{\prime}\right\}_{\mathbf{C o}}^{+}$into the mixedvalence complex $\{\mathbf{F e F e}\}_{\text {co }}$ (Scheme 3 ), which has been isolated and fully characterized spectroscopically (see below). A similar cathodic process was previously observed for $\left\{\mathbf{N i F e}^{\prime}\right\}_{\text {Co }}^{+}$at a close potential $(-1.29 \mathrm{~V})$, but with the reduction occurring on the Ni site $\left(\mathrm{Ni}^{\mathrm{II}}\right.$ to $\left.\mathrm{Ni}{ }^{\mathrm{I}}\right)$. This indicates that the nature of the metal does not notably affect the redox properties of this class of dinuclear complexes.

The second one-electron reduction process is proposed to mainly occur at the bipyridine moiety of the $\mathrm{L}^{\mathrm{N} 2 \mathrm{~S} 2}$ ligand, as shown in the case of $\left\{\mathbf{N i F e}^{\prime}\right\}_{\mathbf{c o}}^{+}$(for which $E_{1 / 2}=-1.90 \mathrm{~V}$ ). ${ }^{25}$ The bipyridine is reduced at a noticeably less negative potential in the case of the FeFe compound, presumably because of structural and electronic differences in the oneelectron reduced species (see below).

Even if the CV displays a reversible redox system for the second reduction process, the proposed radical-based $\left\{\mathbf{F e F e}^{\prime}\right\}$ co intermediate is too unstable to be spectroscopically detected, as for the NiFe complex.ref nat chem

The CV of $\left\{\mathbf{F e F e}^{\prime}\right\}_{\text {Co }}^{+}$also presents an irreversible anodic signal at $0.10 \mathrm{~V}$ (SI), assigned to the $\mathrm{Fe}^{\mathrm{II}}$ to $\mathrm{Fe}^{\mathrm{III}}$ oxidation in the $\mathbf{F e}$ unit. The corresponding cathodic peak at $-0.62 \mathrm{~V}$ is located at the same reduction potential of the previously reported mononuclear $\left[\mathrm{L}^{\mathrm{N} 2 \mathrm{~S} 2} \mathrm{Fe}^{\mathrm{III}} \mathrm{MeCN}\right]^{+}$complex. ${ }^{31}$ This implies that the electrochemically oxidized form of $\left\{\mathbf{F e F e}^{\prime}\right\}_{\text {co }}^{+}$is not stable on the CV timescale and undergoes a fast dissociation into $\left[\mathrm{L}^{\mathrm{N} 2 \mathrm{~S} 2} \mathrm{Fe}^{\mathrm{III}} \mathrm{MeCN}\right]^{+}$and $\left[\mathrm{CpFe}(\mathrm{CO})(\mathrm{MeCN})_{2}\right]^{+}$. Such oxidation process was not observed in the case of $\left\{\mathbf{N i F e}^{\prime}\right\}_{\text {co }}^{+}$.

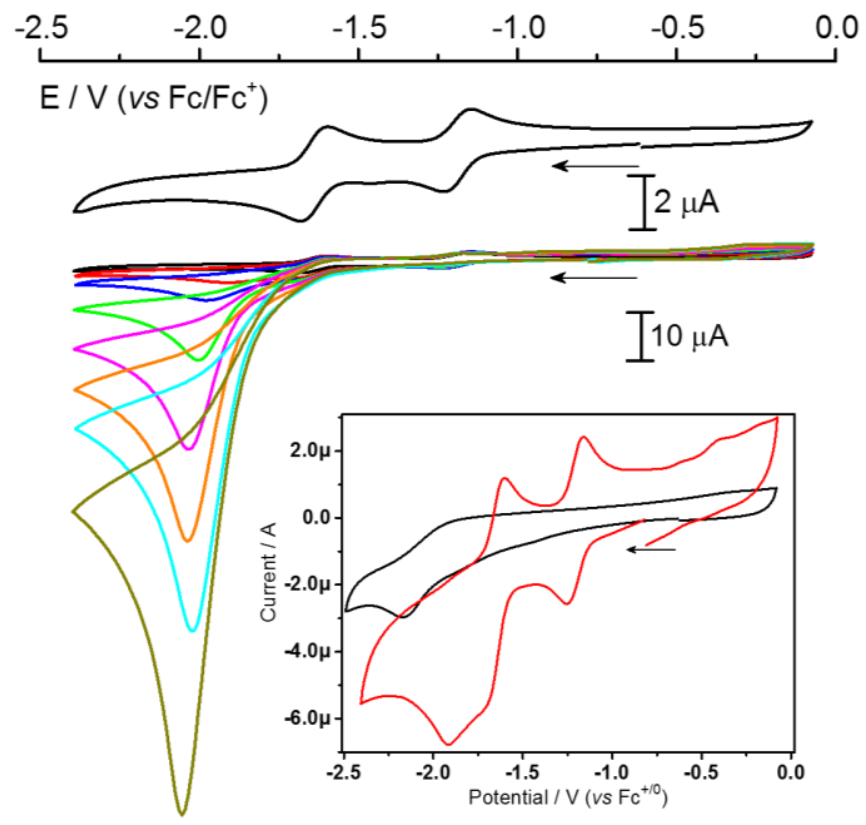

Figure 5. CVs of $\left\{\mathbf{F e F e}^{\prime}\right\}_{\text {Co }}^{+}(0.2 \mathrm{mM})$ in the absence (black) and presence of various amounts of $\mathrm{Et}_{3} \mathrm{NHBF}_{4}$ (red: 1 equiv.; blue: 2 equiv.; green: 5 equiv.; magenta: 10 equiv.; 
orange: 15 equiv.; cyan: 20 equiv.; dark yellow: 30 equiv.) in MeCN. Glassy carbon working electrode, $100 \mathrm{mV} \cdot \mathrm{s}^{-1}, 0.1 \mathrm{M} n-\mathrm{Bu}_{4} \mathrm{NClO}_{4}$. Inset: $\mathrm{CV}$ of $\mathrm{Et}_{3} \mathrm{NHBF}_{4}(0.2 \mathrm{mM})$ in $\mathrm{MeCN}$ in the absence (black) and presence (red) of one equivalent of $\left\{\mathbf{F e F e}^{\prime}\right\}_{\mathbf{C o}}^{+}$.

Spectroscopic characterization of the one-electron reduced species $\left\{\mathrm{FeFe}^{\prime}\right\}_{\text {co }}$. On the basis of the electrochemical properties of $\left\{\mathbf{F e F e}^{\prime}\right\}_{\mathbf{C o}}^{+}$, cobaltocene $\left(\mathrm{CoCp}_{2}, E_{1 / 2}=-1.33\right.$ V) was used to chemically reduce it to generate the mixed-valence $\left\{\mathbf{F e F e}^{\prime}\right\}_{\text {co }}$ complex. This compound could be isolated as a powder and characterized (Table 1). The $v_{\text {co }}$ band at $1896 \mathrm{~cm}^{-1}$ in the IR spectrum suggests the presence of one CO ligand terminally bound to one iron center. We ruled out the coordination of an MeCN ligand because of the absence of a CN vibration in the infrared spectrum (see SI). The zero-field Mössbauer spectrum (powder, $80 \mathrm{~K}$, Figure 6, left) of $\left\{\mathbf{F e F e}^{\prime}\right\}_{\text {co }}$ exhibits two main quadrupole doublets, with $\mathrm{Fe}_{\mathrm{A}}: \delta=0.51 \mathrm{~mm} \cdot \mathrm{s}^{-1}, \Delta \mathrm{E}_{\mathrm{Q}}=2.19 \mathrm{~mm} \cdot \mathrm{s}^{-1}(35 \%)$ and $\mathrm{Fe}_{\mathrm{B}}: \delta=0.33 \mathrm{~mm} . \mathrm{s}^{-1}$, $\Delta \mathrm{E}_{\mathrm{Q}}=0.44 \mathrm{~mm} . \mathrm{s}^{-1}(41 \%)$, which can be assigned to the dinuclear mixed valence complex. The attribution of these parameters to a specific Fe site is arduous and has been made with a combined DFT analysis (see below). The sample also contains two additional minor Fe-based species probably arising from the decomposition of $\left\{\mathbf{F e F e}^{\prime}\right\}_{\mathbf{c o}}$, characterized by two doublets $\delta_{3}\left(\Delta \mathrm{E}_{\mathrm{Q} 3}\right)=0.10(2.16) \mathrm{mm} \cdot \mathrm{s}^{-1}(17 \%)$ and $\delta_{4}\left(\Delta \mathrm{E}_{\mathrm{Q} 4}\right)=1.17$ (3.29) $\mathrm{mm}^{-1}$ (7\%). The former displays parameters close to those of the $\left[\mathrm{CpFe}(\mathrm{CO})_{2} \mathrm{CH}_{2} \mathrm{SiMe}_{3}\right]$ complex $\left(\delta\left(\Delta \mathrm{E}_{Q}\right)=0.099(1.75) \mathrm{mm} \cdot \mathrm{s}^{-1}\right), 3$ and could then be attributed to a mononuclear $\left[\mathrm{FeCOCp}(\text { solvent })_{2}\right]^{+}$complex. The latter parameters are typical of a high spin $\mathrm{Fe}^{\mathrm{II}}$ species and comparable to those found for $\left[\mathrm{Fe}_{2}{ }_{2}\left(\mathrm{~L}^{\mathrm{N} 2 \mathrm{~S}}\right)\left(\mathrm{HL}^{\mathrm{N} 2 \mathrm{~S} 2}\right)\right] \mathrm{BF}_{4}\left(\delta\left(\Delta \mathrm{E}_{\mathrm{Q}}\right) 0.87(3.76) \mathrm{mm} \cdot \mathrm{s}^{-1}\right.$ indicating that this species could correspond to a mononuclear Fe complex containing the $\mathrm{L}^{\mathrm{N} 2 \mathrm{~S} 2}$ ligand.
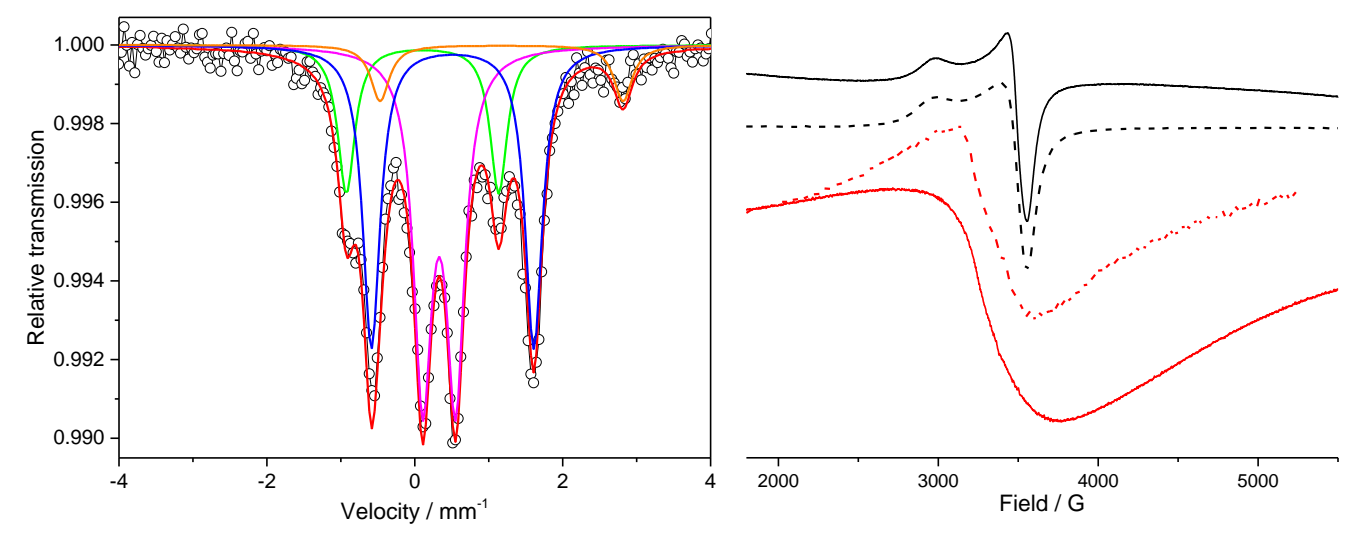

Figure 6. Zero-field ${ }^{57} \mathrm{Fe}$ Mössbauer spectrum (left) at $80 \mathrm{~K}$ of $\left\{\mathbf{F e F e}^{\prime}\right\}_{\text {co }}$ in solid state. X-band EPR spectra (right) of $\left\{\mathbf{F e F e}^{\prime}\right\}_{\text {co }}$ (black solid, in solid state at $22 \mathrm{~K}$; black dash, in frozen MeCN solution at $7 \mathrm{~K}$; red dash, in frozen THF solution at $100 \mathrm{~K}$; red solid, in solid at $100 \mathrm{~K}$. 
The powder EPR spectrum of $\left\{\mathbf{F e F e}^{\prime}\right\}_{\text {co }}$ recorded at $22 \mathrm{~K}$ exhibits an axial signal with $g_{\|}$ $=2.262$ and $g_{\perp}=1.947$, corresponding to a localized $S=1 / 2$ spin system (Figure 6 , right). In contrast, the EPR spectrum recorded on the powder at $100 \mathrm{~K}$ features a broader and more isotropic signal $\left(g_{i}=2.064\right)$, consistent with a delocalized mixed-valence species. Based on this temperature behavior, the electronic structure of $\left\{\mathbf{F e F e}^{\prime}\right\}_{\text {co }}$ can be described as a class II delocalized mixed-valence $\mathrm{Fe}^{\mathrm{I}} \mathrm{Fe}^{\mathrm{II}}$ species.

The identity and valence delocalization of $\left\{\mathbf{F e F e}^{\prime}\right\}$ co has been confirmed also in solution both by EPR and Near Infrared (NIR) spectroscopy. The EPR spectra of $\left\{\mathbf{F e F e}^{\prime}\right\}_{\text {co }}$ in THF/MeCN recorded at $7 \mathrm{~K}$ and $100 \mathrm{~K}$ are similar to the corresponding powder spectra (Figure 6). The NIR spectrum displays a band centered at $1015 \mathrm{~nm}\left(9852 \mathrm{~cm}^{-1}\right), \Delta v_{1 / 2}=$ $2280 \mathrm{~cm}^{-1}$ in agreement with a mixed-valence compound (see below).

To gain more insights on the structural and electronic properties of $\left\{\mathbf{F e F e}^{\prime}\right\}_{\mathbf{c o}}$, different possible structures have been optimized by DFT. Only one computed structure, $\left\{\mathbf{F e F e}^{\prime}\right\}_{\mathbf{C o}}{ }^{*}$, which displays a terminally bound $\mathrm{CO}$ to $\mathbf{F e}$, is consistent with the experimental IR data $\left(v_{\mathrm{CO}}^{\text {calc }}=1904 \mathrm{~cm}^{-1}, v_{\mathrm{CO}}{ }^{\text {exp }}=1896 \mathrm{~cm}^{-1}\right)$. All spectroscopic parameters have been then predicted theoretically for $\left\{\mathbf{F e F e}^{\prime}\right\}_{\mathbf{C O}}{ }^{*}$ (Table 1). TD-DFT calculations predict a NIR transition at $1017 \mathrm{~nm}(f=0.025)$ that perfectly matches the experimental band. This transition is characterized by a strong metal-based character consistent with an intervalence charge transfer (IVCT) transition (Figure 7). The Mössbauer parameters predicted for $\left\{\mathbf{F e F e}^{\prime}\right\}_{\mathbf{c o}} *$ match well with the experimental data, and can thus be assigned to each iron center: for the $\mathbf{F e}$ unit, $\delta_{\text {calc(exp })}=0.27(0.33) \mathrm{mm} \cdot \mathrm{s}^{-1}$; $\Delta \mathrm{E}_{\mathrm{Qcalc}(\exp )}=0.64(0.44) \mathrm{mm} \cdot \mathrm{s}^{-1}$ and for the $\mathbf{F e} \mathbf{e}^{\prime}$ unit, $\delta_{\text {calc(exp })}=0.58(0.51) \mathrm{mm} \cdot \mathrm{s}^{-1} ; \Delta \mathrm{E}_{\mathrm{Qcalc}(\exp )}$ $=1.91(2.19) \mathrm{mm} \cdot \mathrm{s}^{-1}$. The Mülliken spin population is consistent with a valence delocalized species with 0.40 and 0.40 for $\mathbf{F e}$ and $\mathbf{F e}$ ', respectively $(0.03$, each $\mathrm{N}$ and 0.14 , remaining). Finally the $g$ isotropic value obtained from DFT is 2.088 , with a rather small g anisotropy $\left(g_{1}=1.991 ; g_{2}=2.124 ; g_{3}=2.149\right)$ compared to the experimental axial EPR signal recorded at low temperature $(\Delta g=0.31)$. The combination of all these experimental data and theoretical information are consistent with a class II delocalized mixed-valence species with a structure in which the terminal CO is bound the Fe site and not bridging the two metal centers as in the case of the $\left\{\mathbf{N i F e}^{\prime}\right\}_{\text {co }}$ parent complex.
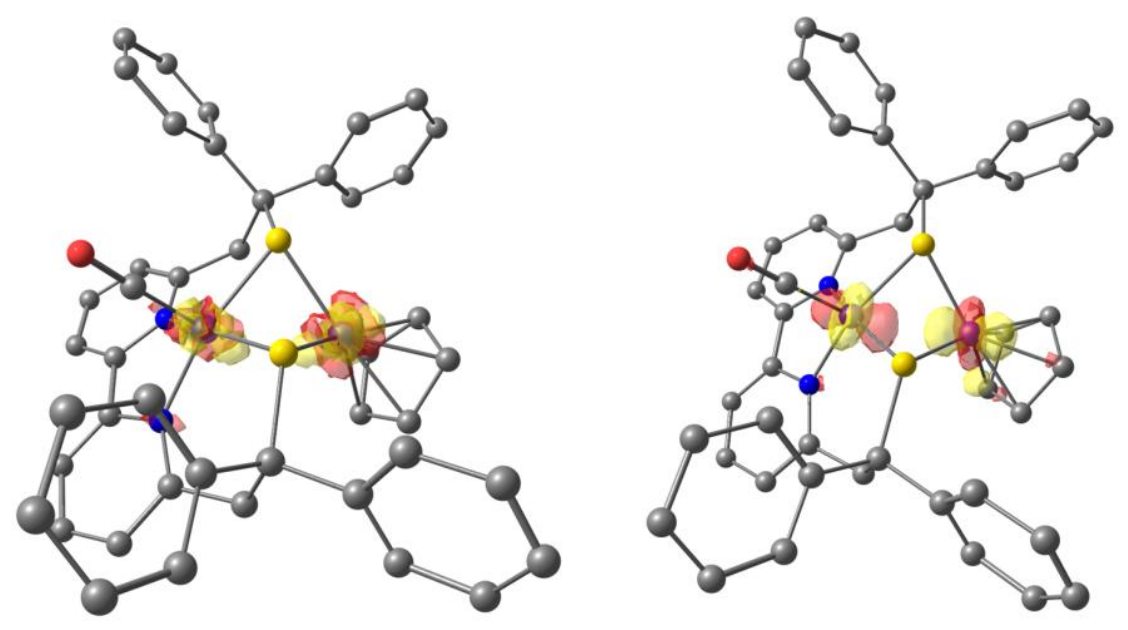
Figure 7. (left) Difference electron densities sketch of the NIR TDDFT-predicted transition for $\left\{\mathbf{F e F e}^{\prime}\right\}_{\mathbf{C o}} *$ at $1017 \mathrm{~nm}$ (yellow = negative, red = positive), (right) localized SOMO of $\left\{\mathbf{F e F e}^{\prime}\right\}_{\text {co }}{ }^{*}$.

The terminal coordination of $\mathrm{CO}$ to the $\left[\mathrm{FeL}^{\mathrm{N} 2 \mathrm{~S} 2}\right]$ moiety in $\left\{\mathbf{F e F e}^{\prime}\right\}_{\mathbf{C o}}{ }^{(*)}$ is consistent with the redox properties of the $\left\{\mathbf{F e F e}^{\prime}\right\}_{\mathbf{c o}} /\left\{\mathbf{F e F e}^{\prime}\right\}_{\text {co }}^{-}$system: although this reduction is proposed to mainly occur at the bipyridine site of $\mathrm{L}^{\mathrm{N} 2 \mathrm{~S} 2}$ as in $\left\{\mathbf{N i F e}^{\prime}\right\}_{\mathbf{C O}}^{+}$, its potential is significantly higher $\left(E_{1 / 2}=-1.65 \mathrm{~V}\right.$ for $\left\{\mathbf{F e F e}^{\prime}\right\}_{\text {Co }}^{+} v s E_{1 / 2}=-1.90 \mathrm{~V}$ for $\left.\left\{\mathbf{N i F e}^{\prime}\right\}_{\text {Co }}^{+}\right)$. The fact that $\left\{\mathbf{F e F e}^{\prime}\right\}_{\text {Co }}$ is easier to reduce than $\left\{\mathbf{N i F e}^{\prime}\right\}_{\text {Co }}$ (i.e. the one-electron reduced form of $\left\{\mathbf{N i F e}^{\prime}\right\}_{\mathbf{C o}}^{+}$) may be due to the stronger back-bonding of the terminal CO ligand in $\left\{\mathbf{F e F e}^{\prime}\right\}_{\text {Co }} v s$ the bridging CO in $\left\{\mathbf{N i F e}^{\prime}\right\}_{\text {co }}$.

Electrocatalytic activity for $\mathrm{H}_{2}$ production of $\left\{\mathbf{F e F e}^{\prime}\right\}_{\mathbf{C O}}^{+}$. The electrocatalytic behavior of $\{\mathbf{F e F e}\}_{\text {Co }}^{+}$for $\mathrm{H}_{2}$ production has been evaluated using $\mathrm{Et}_{3} \mathrm{NHBF}_{4}$ as a mild proton source in $\mathrm{MeCN}\left(\mathrm{pK}_{\mathrm{a}}=18.6\right),{ }^{32}$ conditions that are identical to those used during the investigation of $\left\{\mathbf{N i F e}^{\prime}\right\}_{\mathbf{C o}}^{+}$. (Natchem) In the presence of increasing amounts of $\mathrm{Et}_{3} \mathrm{NHBF}_{4}$ (0.2-6 $\mathrm{mM})$, a catalytic process $\left(E_{\text {cat } / 2}\right.$ in the range -1.89 to $-1.94 \mathrm{~V}$ for a concentration in $\mathrm{Et}_{3} \mathrm{NHBF}_{4}$ in the range 1 to $6 \mathrm{mM} \mathrm{Et}_{3} \mathrm{NHBF}_{4}$, vs $E_{\text {no catalyst }}=-2.16 \mathrm{~V} \mathrm{vs} \mathrm{Fc}^{+} / 0$, potentials being measured at the half-wave) develops at potential $\sim 250 \mathrm{mV}$ more cathodic than the second process generating $\left\{\mathbf{F e F e}^{\prime}\right\}_{\text {co }}^{-}$(Figure 5). The lower value of $E_{\text {cat/2 }}$ compared to $E_{1 / 2}\left\{\mathbf{F e F e}^{\prime}\right\}_{\text {co }} /\left\{\mathbf{F e F e}^{\prime}\right\}_{\text {co }}^{-}$(see the inset of Figure 5) indicates that the two-electron reduced species reacts with a proton to generate an intermediate that needs to be further reduced at a lower potential before to react with a second proton to generate $\mathrm{H}_{2}$ (see below). The plots of catalytic current intensity $\left(i_{\text {cat }}\right)$ versus the concentration of added $\mathrm{Et}_{3} \mathrm{NHBF}_{4}$ provide a linear correlation indicating a diffusion controlled regime for catalysis under these conditions (SI). ${ }^{5}$ Bulk electrolysis experiments performed at $\sim-1.8$ $\mathrm{V}$ vs $\mathrm{Fc}^{+/ 0}$ on a $\mathrm{Hg}$-pool cathode (SI) confirmed the electrocatalytic production of $\mathrm{H}_{2}$ (detected by GC) in the presence of $\{\mathbf{F e F e}\}_{\text {co }}^{+}(\sim 15$ turnovers achieved with $\sim 60 \%$ Faradaic yield within $\sim 20 \mathrm{~min}, \sim 60 \%$ conversion from $10 \mathrm{mM} \mathrm{Et}_{3} \mathrm{NHBF}_{4}$ ).

Mechanistic considerations. The parent $\left\{\mathrm{NiFe}^{\prime}\right\}_{\mathrm{CO}}^{+}$electrocatalyst was shown to follow an E(ECEC) mechanism for $\mathrm{H}_{2}$ production. ${ }^{25,} 27$ The $\left\{\mathbf{N i F e}^{\prime}\right\}_{\text {co }}^{+}$complex undergoes a oneelectron reduction at the $\mathrm{Ni}$ center to afford [ $\left.\mathrm{L}^{\mathrm{N} 2 \mathrm{~S} 2} \mathrm{Ni}^{\mathrm{I}} \mathrm{Fe}^{\mathrm{II}} \mathrm{Cp}(\mathrm{CO})\right]\left(\left\{\mathbf{N i F e}^{\prime}\right\}_{\mathbf{C O}}\right)$, which is further reduced to produce the radical based $\left[\mathrm{L}^{\mathrm{N} 2 \mathrm{~S} 2{ }^{\circ}} \mathrm{Ni}^{\mathrm{i}} \mathrm{Fe}{ }^{\mathrm{II}} \mathrm{Cp}(\mathrm{CO})\right]^{-}$complex that is then protonated on $\mathrm{Fe}$ affording a semi-bridging hydride $\left[\mathrm{L}^{\mathrm{N} 2 \mathrm{~S} 2} \mathrm{Ni}^{\mathrm{II}}(\mathrm{H}) \mathrm{Fe}^{\mathrm{II}} \mathrm{Cp}(\mathrm{CO})\right]^{-}$. $\left[\mathrm{L}^{\mathrm{N} 2 \mathrm{~S} 2} \mathrm{Ni}^{\mathrm{II}}(\mathrm{H}) \mathrm{Fe}^{\mathrm{II}} \mathrm{Cp}(\mathrm{CO})\right]^{-}$. The complex then needs to be further reduced before to react with a second proton to produce $\mathrm{H}_{2}$.

Based on our present experimental results and on the mechanism of the parent $\left\{\mathbf{N i F e}^{\prime}\right\}_{\text {Co }}^{+}$catalyst, ${ }^{25-27}$ a similar E(ECEC) mechanism is proposed for electrocatalytic $\mathrm{H}_{2}$ production with $\left\{\mathbf{F e F e}^{\prime}\right\}_{\text {co }}^{+}$(Scheme 3$)$. 


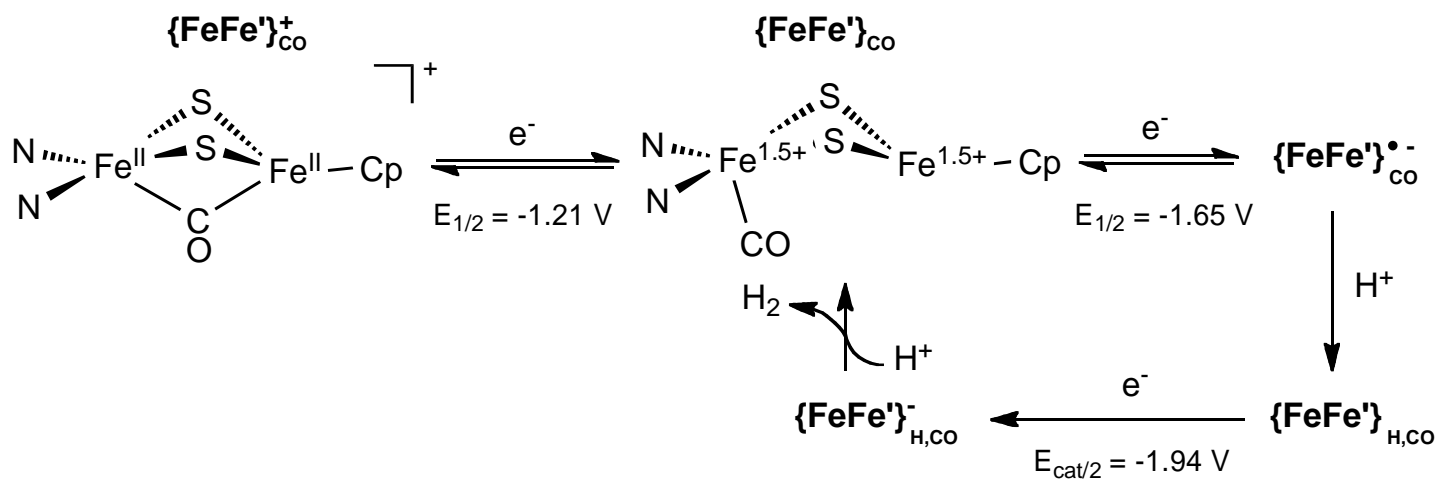

Scheme 3. Proposed catalytic pathways for $\mathrm{H}_{2}$ evolution with $\left\{\mathbf{F e F e}^{\prime}\right\}_{\text {co }}^{+}$catalyst (potentials are referred to $\mathrm{Fc}^{+/ 0}$ ).

The first reduction generates the spectroscopically characterized mixed-valence $\left\{\mathbf{F e F e}^{\prime}\right\}_{\text {co }}$ complex (see above). This species undergoes a second one-electron reduction to form $\left\{\mathbf{F e F e}^{\prime}\right\}$ co. The fact that the catalytic wave occurs at a reduction potential lower than $E_{1 / 2}=-1.65 \mathrm{~V}$ versus $\mathrm{Fc}^{+/ 0}$ (corresponding to the $\left\{\mathbf{F e F e}^{\prime}\right\}_{\mathbf{c o}} /\left\{\mathbf{F e F e}^{\prime}\right\}_{\text {co }}^{-}$redox system) evidences that: (i) $\left\{\mathbf{F e F e}^{\prime}\right\}^{--}$is protonated to generate either a Fe-hydride or thiol-containing intermediate, $\left\{\mathbf{F e F e}^{\prime}\right\}_{\mathbf{H}, \mathbf{C O}}$ and (ii) this protonated species needs to be reduced before reacting with a second proton to produce $\mathrm{H}_{2}$. $\left\{\mathbf{F e F e}^{\prime}\right\}_{\text {Co }}$ is thus regenerated for another electrocatalytic cycle.

Interestingly, for the FeFe electrocatalyst the E(ECEC) cycle can be experimentally validated, while for the parent $\mathrm{NiFe}$ complex it was mainly predicted by DFT calculations. In the case of $\left\{\mathbf{N i F e}^{\prime}\right\}_{\text {co }}^{+}$the predicted potential of the third reduction process (that occurs after the first protonation step) is higher than the second one $\left(E^{0}\right.$ calc $=-1.42 \mathrm{~V}$ and $E_{\text {calc }}^{0}=-1.77 \mathrm{~V} v s \mathrm{Fc}^{+/ 0}$, respectively ${ }^{27}$ and thus was not detectable. ${ }^{25}$ In contrast, for $\left\{\mathbf{F e F e}^{\prime}\right\}_{\text {co }}^{+}$the third reduction process can be directly observed since it occurs at a lower reduction potential $\left(E_{\text {cat } / 2}=-1.94 \mathrm{~V}\right.$ vs $\left.E_{1 / 2}=-1.65 \mathrm{~V}\right)$.

\section{Discussion}

In the present work, we investigated a $\mathrm{Fe}^{\mathrm{II}} \mathrm{Fe}^{\mathrm{II}}$ complex as the homodinuclear counterpart of the efficient heterodinuclear NiFe HER electrocatalyst $\left[\mathrm{L}^{\mathrm{N} 2 \mathrm{~S} 2} \mathrm{Ni}^{\mathrm{II}} \mathrm{Fe}^{\mathrm{II}} \mathrm{Cp}(\mathrm{CO})\right]^{+}$, in which the $\mathrm{Ni}^{\mathrm{II}}$ ion has now been replaced by $\mathrm{Fe}^{\mathrm{II}}$. The objective of this study is to evaluate the influence of the nature of the metal ion located in the N2S2 site on the HER reactivity.

Structural differences between the two $\mathrm{M}^{\mathrm{II}} \mathrm{Fe}^{\mathrm{II}}$ complexes, both in the solid state and in solution, have been observed. In the solid state, the FeFe complex could not be isolated in an isostructural form of $\left\{\mathbf{N i F e}^{\prime}\right\}$ co since it contains two CO molecules: one bound to $\mathbf{F e}^{\prime}(\{\mathrm{FeCp}\})$ in a semi-bridging manner and one terminally bound to the Fe center ( $\left.\left\{\mathrm{FeL}^{\mathrm{N} 2 \mathrm{~S} 2}\right\}\right)$. In low-concentrated MeCN solutions, one CO ligand is removed and the remaining CO ligand is bridging, whereas in $\left\{\mathbf{N i F e}^{\prime}\right\}_{\text {Co }}^{+}$it is terminally-bound to the $\mathbf{F e}^{\prime}$ moiety. Stabilizing a four-coordinate $\mathrm{Fe}^{\mathrm{II}}$ ion in the Fe site is difficult. In the specific case 
of the $\mathrm{L}^{\mathrm{N} 2 \mathrm{~S} 2}$ ligand, even if mononuclear tetracoordinated [ML ${ }^{\mathrm{N} 2 \mathrm{~S} 2}$ ] complexes have been previously isolated with $\mathrm{M}=\mathrm{Co}^{\mathrm{II}}, 33 \mathrm{Cu}^{\mathrm{II}}, 34 \mathrm{Zn}^{\mathrm{II}} 35$ and $\mathrm{Ni}^{\mathrm{II}}$, ${ }^{36}$ we did not succeed in isolating the corresponding [FeL $\left.{ }^{\mathrm{N} 2 \mathrm{~S} 2}\right]$ complex. Instead, the mononuclear $\left[\mathrm{FeL}^{\mathrm{N} 2 \mathrm{~S} 2}(\mathrm{Cl})\right]^{-}$ and the dinuclear $\left[\mathrm{Fe}_{2}\left(\mathrm{~L}^{\mathrm{N} 2 \mathrm{~S} 2}\right)\left(\mathrm{L}^{\mathrm{N} 2 \mathrm{~S} 2} \mathrm{H}\right)\right]^{+}$complexes were obtained, in which the Fe ${ }^{\mathrm{II}}$ ions are five-coordinated. ${ }^{29}, 31$ Likewise, in $\left[\left(\mathrm{N}_{2} \mathrm{~S}_{2}\right)(\mathrm{Fe}-\mathrm{NO}) \mathrm{Fe}(\mathrm{CO}) \mathrm{Cp}\right]^{+}$(Scheme 1) Darensbourg et al. needed a NO co-ligand to complete the N2S2 coordination of one Fe center. ${ }^{24}$ For $\left[(\mathrm{dppe}) \mathrm{Ni}(\mu-\mathrm{pdt}) \mathrm{Fe}(\mathrm{CO})_{3}\right]$, an additional $\mathrm{CO}$ was required to isolate the homobimetallic congener $\left[(\mathrm{dppe})(\mathrm{CO}) \mathrm{Fe}\left(\mu\right.\right.$-pdt) $\left.\mathrm{Fe}(\mathrm{CO})_{3}\right]$, as in the present case. ${ }^{17}$

Since our aim is to evaluate the role of the metal in the catalytic process, the most relevant species to be compared are the one-electron reduced complexes, $\left\{\mathbf{M F e}^{\prime}\right\}_{\mathbf{c o}}$, which represent the entrance in the proposed catalytic cycles. Even if only one CO is present in both structures, it is terminally bound to the $\left\{\mathrm{FeL}^{\mathrm{N} 2 \mathrm{~S} 2}\right\}$ moiety in $\left\{\mathbf{F e F e}^{\prime}\right\}_{\mathbf{c o}}$, while it bridges the $\mathrm{Ni}$ and Fe ions in $\left\{\mathbf{N i F e}^{\prime}\right\}_{\text {co }}$. The electronic structure is also notably different since $\left\{\mathbf{F e F e}^{\prime}\right\}_{\text {co }}$ displays a mixed-valence character of type II, whereas in $\left\{\mathbf{N i F e}^{\prime}\right\}_{\text {co }}$ the spin-density is almost exclusively localized on the Ni site.

Concerning the electrocatalytic HER process, it occurs in both cases through an E(ECEC) mechanism: for $\left\{\mathbf{F e F e}^{\prime}\right\}_{\mathbf{c o}}^{+}$, cyclic voltammetry experiments carried out in the presence of $\mathrm{Et}_{3} \mathrm{NH}^{+}$(see Figure 5) demonstrate experimentally this pathway, while for $\left\{\mathbf{N i F e}^{\prime}\right\}_{\mathbf{C o}}^{+}$it was mainly supported by DFT. The overpotential requirement of the $\left\{\mathbf{F e F e}^{\prime}\right\}_{\mathbf{C o}}^{+}$ electrocatalyst $(\eta=730 \mathrm{mV})$ is slightly higher than that of $\left\{\mathbf{N i F e}^{\prime}\right\}_{\mathbf{C O}}^{+}(\eta=690 \mathrm{mV})$. Indeed, even if the second E-step occurs at a less negative potential for $\left\{\mathbf{F e F e}^{\prime}\right\}_{\mathbf{c}}^{+}$, the catalytic wave develops at a lower potential for the FeFe compound (see above). Finally, the FeFe and NiFe systems display comparable catalytic stabilities in MeCN solution (TON $\{\mathbf{F e F e}\}_{\text {Co }}^{+}=15$, TON $\{\mathbf{N i F e}\}_{\text {Co }}^{+}=16$ ).

All together, these data suggest that even if the electronic and structural parameters of the key intermediates, i.e. the one-electron reduced $\{\mathbf{M F e}\}_{\text {co }}$ species, slightly differs, the nature of the metal ion located in the N2S2 ligand does not significantly impact the catalytic HER efficiency and an E(ECEC) pathway is proposed in both cases. The reactivity is most likely dominated by the coordinating and electronic properties of the $\mathrm{L}^{\mathrm{N} 2 \mathrm{~S} 2}$ ligand itself, especially owing to its non-innocent redox character. In fact, for both $\mathrm{NiFe}$ and FeFe electrocatalysts, the second reduction process is proposed to occur on the bipyridine unit of $\mathrm{L}^{\mathrm{N} 2 \mathrm{~S} 2}$. In addition, DFT calculations carried out for the NiFe system predict that the third reduction process also occurs on the bipyridine unit. Since, a similar mechanism is suggested for the FeFe system, it clearly appears that the redox activity of the $\mathrm{L}^{\mathrm{N} 2 \mathrm{~S} 2}$ ligand, especially its bipyridine unit, partly drives the entire catalytic process.

Interestingly, the present study describes a rare example of an [FeFe] $\mathrm{H}_{2}$ ase model that mimics the iron oxidation states relevant to enzyme reactivity. The $\left\{\mathbf{F e F e}^{\prime}\right\}_{\text {co }}$ mimics the $\mathrm{H}_{\mathrm{ox}}$ state (scheme 1) and an ECEC pathway generates $\mathrm{H}_{2}$ from both $\left\{\mathbf{F e F e}^{\prime}\right\}_{\text {co }}$ and the $\mathrm{H}_{\mathrm{ox}}$ state. By contrast, most of the reported [FeFe] $\mathrm{H}_{2}$ ase models involve more reduced complexes, $\mathrm{Fe}^{\mathrm{I}} \mathrm{Fe}^{\mathrm{I}}$ or $\mathrm{Fe}^{0} \mathrm{Fe}^{\mathrm{I}}$, stabilized through the coordination of phosphines and/or multiple CO ligands, as the resting state. ${ }^{1-2}$ The $\left\{\mathbf{F e F e}^{\prime}\right\}_{\mathbf{c o}^{-}}^{-}$intermediate formed during the electrocatalytic cycle parallels the generation of the super-reduced state, 
proposed to be involved during the catalytic cycle of [FeFe] hydrogenase. 40 In this case, the bipyridine moiety acts as an electron reservoir for the FeFe catalyst, like the proximal [4Fe4S] cluster in [FeFe] $\mathrm{H}_{2}$ ase.41, 42

Regarding the protonation steps, especially the one that is proposed to occur after the generation of the two electron reduced species, $\{\mathbf{F e F e}\}_{\mathbf{c o}}^{-}$, it can lead to a Fe-hydride species or to a thiol-containing intermediate, $\{\mathbf{F e F e}\}_{\mathbf{H}, \mathbf{C o}}$. Based on several DFT investigations, it has been proposed that such type of (hetero)dinuclear complexes with bridging thiolates display the propensity to protonate a thiolate during the catalytic process followed by the decoordination of the corresponding thiol, because of the hemilability properties of these metallodithiolate ligands.(darensbourg et hall, acs catal) 24, 26-27, 37. In contrast, in the present case of $\{\mathbf{F e F e}\}_{\mathbf{C} 0}^{+}$, we propose the generation of a terminal hydride on the $\mathbf{F e}^{\prime}$ site based on the fact that (i) a metal-hydride is generated during the first protonation of the parent $\{\mathbf{N i F e}\}_{\text {co }}^{+}$electrocatalyst, and (ii) the Fe' site is proposed to have a vacant site based on the DFT-predicted structure of $\left\{\mathbf{F e F e}^{\prime}\right\}_{\mathbf{c o}}$.

\section{Conclusion}

In summary, we succeed to compare the activity between a [FeFe] $\mathrm{H}_{2}$ ase mimic and its previously reported [NiFe] analogue, two dinuclear HER catalysts in which only the nature of the metal ( $\mathrm{Ni}$ vs $\mathrm{Fe}$ ) in the $\left\{\mathrm{ML}^{\mathrm{N} 2 \mathrm{~S}} 2\right\}$ metallodithiolate ligand is modified. Although the structure of the catalytic intermediates, especially the one electron reduced species, notably differs, the activity of the two electrocatalysts is similar. This might be explained by the non-innocent redox activity of the $\mathrm{L}^{\mathrm{N} 2 \mathrm{~S} 2}$ ligand that is proposed to dominate the catalytic process. Further studies are needed at probing the full catalytic cycle, deciphering between terminal or bridging hydride ligands as catalytic intermediates and investigating if hemilability of the metallodithiolate ligand is at play in the $\mathrm{H}_{2}$ evolution process mediated by $\{\mathbf{F e F e}\}_{\mathbf{C o}}^{+}$.

Acknowledgements. The authors gratefully acknowledge research support of this work by the China Scholarship Council (LW), the French National Agency for Research in the framework of the "Investissements d'avenir" program (ANR-15-IDEX-02), the Labex ARCANE, the CBH-EUR-GS (ANR-17-EURE-0003) and the ANR-DFG (ANR-16CE92_0012_01), and the Deutsche Forschungsgemeinschaft (DFG Me1313/14-1, NiFeMim).

\section{References}

1. Lubitz, W.; Ogata, H.; Rüdiger, O.; Reijerse, E., Hydrogenases. Chem. Rev. 2014, $114,4081-4148$. 
2. Schilter, D.; Camara, J. M.; Huynh, M. T.; Hammes-Schiffer, S.; Rauchfuss, T. B., Hydrogenase Enzymes and Their Synthetic Models: The Role of Metal Hydrides. Chem. Rev. 2016, 116, 8693-8749.

3. Nicolet, Y.; Piras, C.; Legrand, P.; Hatchikian, C. E.; Fontecilla-Camps, J. C., Desulfovibrio desulfuricans iron hydrogenase: the structure shows unusual coordination to an active site Fe binuclear center. Structure 1999, 7, 13-23.

4. $\quad$ Chen, Z.; Lemon, B. J.; Huang, S.; Swartz, D. J.; Peters, J. W.; Bagley, K. A., Infrared Studies of the CO-Inhibited Form of the Fe-Only Hydrogenase from Clostridium pasteurianum I: Examination of Its Light Sensitivity at Cryogenic Temperatures. Biochemistry 2002, 41, 2036-2043.

5. $\quad$ Peters, J. W.; Lanzilotta, W. N.; Lemon, B. J.; Seefeldt, L. C., X-ray Crystal Structure of the Fe-Only Hydrogenase (CpI) from Clostridium pasteurianum to 1.8 Angstrom Resolution. Science 1998, 282, 1853.

6. Volbeda, A.; Charon, M.-H.; Piras, C.; Hatchikian, E. C.; Frey, M.; Fontecilla-Camps, J. C., Crystal structure of the nickel-iron hydrogenase from Desulfovibrio gigas. Nature 1995, 373, 580-587.

7. Coutard, N.; Kaeffer, N.; Artero, V., Molecular engineered nanomaterials for catalytic hydrogen evolution and oxidation. Chem. Commun. 2016, 52, 13728-13748.

8. Can, M.; Armstrong, F. A.; Ragsdale, S. W., Structure, Function, and Mechanism of the Nickel Metalloenzymes, CO Dehydrogenase, and Acetyl-CoA Synthase. Chem. Rev. 2014, 114, 4149-4174.

9. Ash, P. A.; Hidalgo, R.; Vincent, K. A., Proton Transfer in the Catalytic Cycle of [NiFe] Hydrogenases: Insight from Vibrational Spectroscopy. ACS Catal. 2017, 7, 24712485.

10. Ogata, H.; Lubitz, W.; Higuchi, Y., Structure and function of [NiFe] hydrogenases. J. Biochem. 2016, 160, 251-258.

11. Hidalgo, R.; Ash, P. A.; Healy, A. J.; Vincent, K. A., Infrared Spectroscopy During Electrocatalytic Turnover Reveals the Ni-L Active Site State During H2 Oxidation by a NiFe Hydrogenase. Angew. Chem. Int. Ed. 2015, 54, 7110-7113.

12. Ogata, H.; Nishikawa, K.; Lubitz, W., Hydrogens detected by subatomic resolution protein crystallography in a [lsqb]NiFe[rsqb] hydrogenase. Nature 2015, 520, 571-574.

13. Tard, C.; Pickett, C. J., Structural and Functional Analogues of the Active Sites of the [Fe]-, [NiFe]-, and [FeFe]-Hydrogenases. Chem. Rev. 2009, 109, 2245-2274.

14. Adamska, A.; Silakov, A.; Lambertz, C.; Ruediger, O.; Happe, T.; Reijerse, E.; Lubitz, W., Identification and Characterization of the "Super-Reduced" State of the H-Cluster in FeFe Hydrogenase: A New Building Block for the Catalytic Cycle? Angew. Chem. Int. Ed. 2012, 51, 11458-11462.

15. Mulder, D. W.; Ratzloff, M. W.; Shepard, E. M.; Byer, A. S.; Noone, S. M.; Peters, J. W.; Broderick, J. B.; King, P. W., EPR and FTIR Analysis of the Mechanism of H2 Activation by [FeFe]-Hydrogenase HydA1 from Chlamydomonas reinhardtii. J. Am. Chem. Soc. 2013, 135, 6921-6929.

16. Simmons, T. R.; Berggren, G.; Bacchi, M.; Fontecave, M.; Artero, V., Mimicking hydrogenases: From biomimetics to artificial enzymes. Coord. Chem. Rev. 2014, 270-271, 127-150.

17. Gloaguen, F.; Rauchfuss, T. B., Small molecule mimics of hydrogenases: hydrides and redox. Chem. Soc. Rev. 2009, 38, 100-108.

18. Kaur-Ghumaan, S.; Stein, M., [NiFe] hydrogenases: how close do structural and functional mimics approach the active site? Dalton Trans. 2014, 43, 9392-9405. 
19. Tard, C.; Liu, X.; Ibrahim, S. K.; Bruschi, M.; Gioia, L. D.; Davies, S. C.; Yang, X.; Wang, L.-S.; Sawers, G.; Pickett, C. J., Synthesis of the H-cluster framework of iron-only hydrogenase. Nature 2005, 433, 610-613.

20. Camara, J. M.; Rauchfuss, T. B., Combining acid-base, redox and substrate binding functionalities to give a complete model for the FeFe -hydrogenase. Nature Chem. 2012, 4, 26-30.

21. Rauchfuss, T. B., Diiron Azadithiolates as Models for the [FeFe]-Hydrogenase Active Site and Paradigm for the Role of the Second Coordination Sphere. Acc. Chem. Res. 2015, 48, 2107-2116.

22. Barton, B. E.; Whaley, C. M.; Rauchfuss, T. B.; Gray, D. L., Nickel-Iron Dithiolato Hydrides Relevant to the [NiFe]-Hydrogenase Active Site. J. Am. Chem. Soc. 2009, 131, 6942-6943.

23. Zhu, W.; Marr, A. C.; Wang, Q.; Neese, F.; Spencer, D. J. E.; Blake, A. J.; Cooke, P. A.; Wilson, C.; Schröder, M., Modulation of the electronic structure and the Ni-Fe distance in heterobimetallic models for the active site in [NiFe] hydrogenase. Proc. Natl. Acad. Sci. U. S. A. 2005, 102, 18280-18285.

24. Ding, S.; Ghosh, P.; Lunsford, A. M.; Wang, N.; Bhuvanesh, N.; Hall, M. B.; Darensbourg, M. Y., Hemilabile Bridging Thiolates as Proton Shuttles in Bioinspired H2 Production Electrocatalysts. J. Am. Chem. Soc. 2016, 138, 12920-12927.

25. Brazzolotto, D.; Gennari, M.; Queyriaux, N.; Simmons, T. R.; Pécaut, J.; Demeshko, S.; Meyer, F.; Orio, M.; Artero, V.; Duboc, C., Nickel-centred proton reduction catalysis in a model of [NiFe] hydrogenase. Nature Chem. 2016, 8, 1054-1060.

26. Brazzolotto, D.; Wang, L. K.; Tang, H.; Gennari, M.; Queyriaux, N.; Philouze, C.; Demeshko, S.; Meyer, F.; Orio, M.; Artero, V.; Hall, M. B.; Duboc, C., Tuning Reactivity of Bioinspired NiFe -Hydrogenase Models by Ligand Design and Modeling the CO Inhibition Process. ACS Catal. 2018, 8, 10658-10667.

27. Tang, H.; Hall, M. B., Biomimetics of [NiFe]-Hydrogenase: Nickel- or Iron-Centered Proton Reduction Catalysis? J. Am. Chem. Soc. 2017, 139, 18065-18070.

28. Ahmed, M. E.; Chattopadhyay, S.; Wang, L. K.; Brazzolotto, D.; Pramanik, D.; Aldakov, D.; Fize, J.; Morozan, A.; Gennari, M.; Duboc, C.; Dey, A.; Artero, V., Hydrogen Evolution from Aqueous Solutions Mediated by a Heterogenized NiFe -Hydrogenase Model: Low pH Enables Catalysis through an Enzyme-Relevant Mechanism. Angew. Chem. Int. Ed. 2018, 57, 16001-16004.

29. Wang, L.; Gennari, M.; Cantú Reinhard, F. G.; Gutiérrez, J.; Morozan, A.; Philouze, C.; Demeshko, S.; Artero, V.; Meyer, F.; de Visser, S. P.; Duboc, C., A Non-Heme Diiron Complex for (Electro)catalytic Reduction of Dioxygen: Tuning the Selectivity through Electron Delivery. J. Am. Chem. Soc. 2019, 141, 8244-8253.

30. Nicolet, Y.; de Lacey, A. L.; Vernède, X.; Fernandez, V. M.; Hatchikian, E. C.; Fontecilla-Camps, J. C., Crystallographic and FTIR Spectroscopic Evidence of Changes in Fe Coordination Upon Reduction of the Active Site of the Fe-Only Hydrogenase from Desulfovibrio desulfuricans. J. Am. Chem. Soc. 2001, 123, 1596-1601.

31. Wang, L. K.; Reinhard, F. G. C.; Philouze, C.; Demeshko, S.; de Visser, S. P.; Meyer, F.; Gennari, M.; Duboc, C., Solvent- and Halide-Induced (Inter)conversion between Iron(II)-Disulfide and Iron(III)-Thiolate Complexes. Chem. Eur. J. 2018, 24, 11973-11982. 32. Izutsu, K., Acid-Base Dissociation Constants in Dipolar Aprotic Solvents. Blackwell Scientific: Oxford, U.K. , 1990.

33. Gennari, M.; Gerey, B.; Hall, N.; Pécaut, J.; Vezin, H.; Collomb, M. N.; Orio, M.; Duboc, C., Structural, spectroscopic and redox properties of a mononuclear Co-II thiolate 
complex - the reactivity toward S-alkylation: an experimental and theoretical study. Dalton Trans. 2012, 41, 12586-12594.

34. Gennari, M.; Pécaut, J.; Collomb, M. N.; Duboc, C., A Copper Thiolate Centre for Electron Transfer: Mononuclear versus Dinuclear Complexes. Dalton Trans. 2012, 41, 3130-3133

35. Gennari, M.; Retegan, M.; DeBeer, S.; Pecaut, J.; Neese, F.; Collomb, M. N.; Duboc, C., Experimental and Computational Investigation of Thiolate Alkylation in Ni-II and Zn-II Complexes: Role of the Metal on the Sulfur Nucleophilicity. Inorg. Chem. 2011, 50, 10047-10055.

36. Gennari, M.; Orio, M.; Pécaut, J.; Neese, F.; Collomb, M.-N.; Duboc, C., Reversible Apical Coordination of Imidazole between the $\mathrm{Ni}(\mathrm{III})$ and $\mathrm{Ni}(\mathrm{II})$ Oxidation States of a Dithiolate Complex: A Process Related to the Ni Superoxide Dismutase. Inorg. Chem. 2010, 49, 6399-6401.

37. Ding, S.; Ghosh, P.; Darensbourg, M. Y.; Hall, M. B., Interplay of hemilability and redox activity in models of hydrogenase active sites. Proc. Natl. Acad. Sci. USA 2017, 114, E9775-E9782. 